\title{
Time-varying fiscal spending multipliers in the UK
}

\author{
Christian Glocker ${ }^{1}$ \& Giulia Sestieri ${ }^{2}$ \& \\ Pascal Towbin ${ }^{3}$
}

January 2019, WP \#643

\begin{abstract}
We study government spending multipliers of the UK economy using a time-varying parameter factor augmented vector autoregressive model (TVP-FAVAR) over the period 1966:Q1-2015:Q4. We show that government spending multipliers vary over time and that most of the variation is cyclical: multipliers for GDP are typically above one in recessions and below one in expansions. Regarding the drivers of the cyclical variation, our results are consistent with theories emphasizing the role of financial frictions and economic slack. We find no evidence that multipliers are larger at the zero lower bound. Structural factors seem to play a lesser role and multipliers do not exhibit a clear trend. We conclude that fiscal policy recommendations should take into account the position of the economy in the cycle in assessing their effectiveness and that the impact of government spending shocks is limited in the UK in non-recessionary periods. ${ }^{4}$
\end{abstract}

Keywords: Government spending shocks, Fiscal transmission mechanism, Time-varying parameter models, Business cycle

JEL classification: C32, E62, H30, H50

1 Austrian Institute of Economic Research, christian.glocker@wifo.ac.at

2 Banque de France, giulia.sestieri@banque-france.fr

3 Swiss National Bank, pascal.towbin@snb.ch

${ }^{4}$ The authors would like to thank Laurent Ferrara, Christian Kleiber, Matthieu Lemoine and seminar participants at the Banque de France for helpful comments and discussions. We are very grateful to Valérie Ghiringhelli for outstanding research assistance. The views, opinions, findings, and conclusions or recommendations expressed in this paper are strictly those of the author(s). They do not necessarily reflect the views of the Banque de France, the Eurosystem or the Schweizerische Nationalbank (SNB). The SNB takes no responsibility for any errors or omissions in, or for the correctness of, the information contained in this paper.

Working Papers reflect the opinions of the authors and do not necessarily express the views of the Banque de France. This document is available on publications.banque-france.fr/en 


\section{UK fiscal spending multiplier for output (2-year cumulative multiplier)}

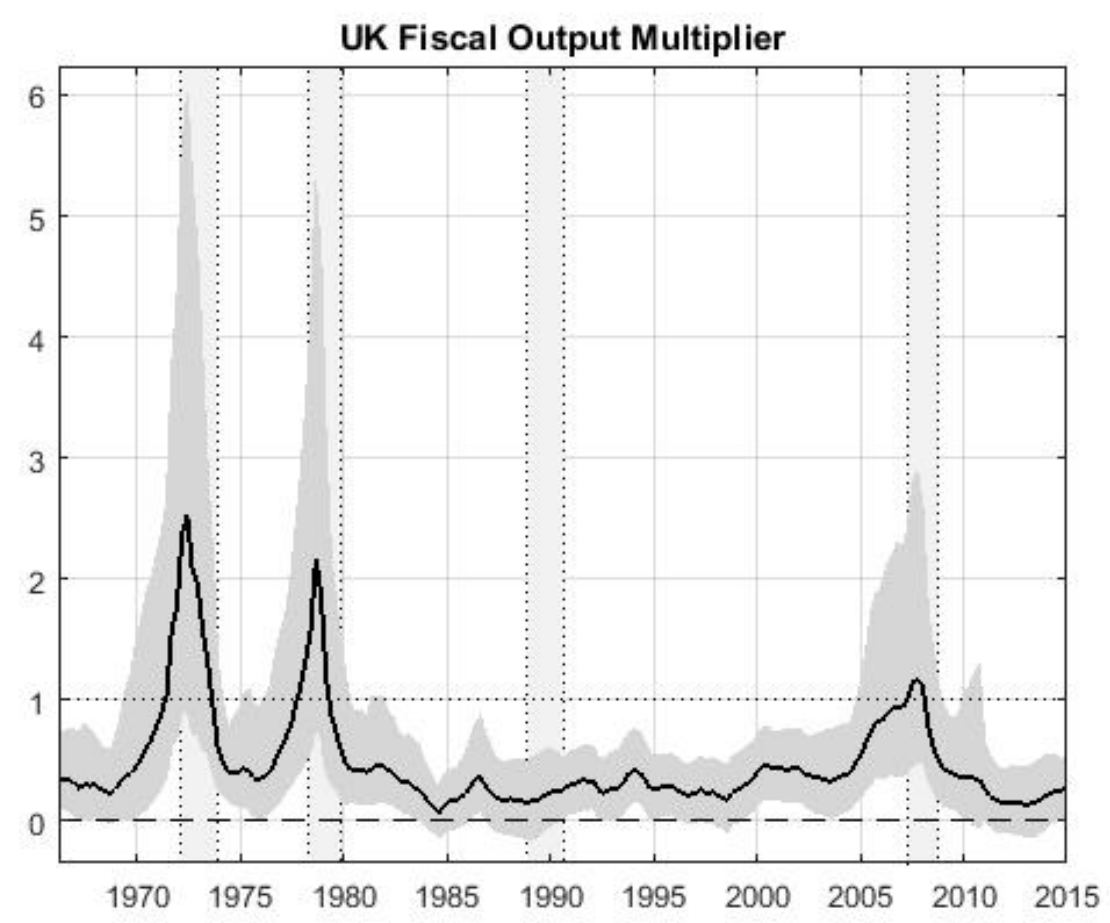

Source: authors' computations.

In this paper, we study whether the effect of fiscal stimuli on economic activity - the socalled government spending multiplier - varies over time, taking the example of the UK over the past 50 years. The UK is an interesting example since in its recent economic history there have been several moments characterized by intense debates about how changes in government spending may affect the economy. In 2008, the UK was one of the major advanced countries, together with the U.S., who implemented a strong countercyclical fiscal expansion as a response to the financial crisis. The reversal of the fiscal stimulus, begun in 2010, has given rise to a harsh debate on austerity.

Economic theory offers a number of reasons why fiscal spending multipliers may be timevarying. They can be broadly divided into two groups: cyclical theories and structural theories. Prominent examples of cyclical theories put forward three main explanations for time variation: economic slack, financial frictions, and the zero lower bound (ZLB) on nominal interest rates. On the structural side, explanations for time-variation in government spending multipliers include trade openness and the amount of fiscal space, among others.

This paper contributes to the literature on the non-linear effects of fiscal policy by using an econometric framework (a time-varying parameter factor augmented vector autoregressive model, TVP-FAVAR) that is flexible enough to distinguish cyclical variations from structural changes in government spending multipliers and rich enough to discriminate between different theoretical transmission mechanisms.

Our results show that UK government spending multipliers vary over time and that most of the variation is cyclical. They are typically above one in recessions and below one in expansion periods. By contrast, multipliers do not exhibit a visible structural trend. When 
we dig deeper to understand which factors drive the cyclical variation, the results of the model are consistent with theories emphasizing the role of financial frictions and economic slack. Typically, a larger impact on output is accompanied by stronger effects on private sector credit generation, suggesting that fiscal expansions help relieving credit constraints. Finally, according to our findings, UK multipliers are not systematically higher during the recent zero lower bound period.

Given the evidence from our model, we conclude that fiscal policy recommendations should take into account the position of the economy in the cycle in assessing their effectiveness. In particular, we find that in non-recessionary periods the impact of fiscal spending shocks is limited as crowding-out effects are large, suggesting a cautionary tale for fiscal policy to stimulate output in the UK during expansionary phases of the business cycle.

\title{
Multiplicateurs de dépenses publiques au Royaume- Uni et leur évolution dans le temps
}

\begin{abstract}
RÉSUMÉ
Nous étudions les multiplicateurs de dépenses publiques au Royaume-Uni en utilisant un modèle autorégressive à facteurs FAVAR à coefficients variables dans le temps. Nous montrons que les multiplicateurs de dépenses publiques varient dans le temps et que la plupart de cette variation est cyclique : les multiplicateurs sont typiquement supérieurs à un dans les périodes de récession est inférieures à un dans les périodes d'expansion. En ce qui concerne les moteurs des variations cycliques, nos résultats sont en accord avec les théories économiques qui mettent l'accent sur le rôle des frictions financières et des capacités excédentaires dans l'économie. Nous ne trouvons pas d'éléments de preuve à l'appui de l'hypothèse que les multiplicateurs soient plus élevés quand les taux d'intérêts sont proches de la borne du zéro. Certains facteurs structurels semblent joueur un moindre rôle dans l'évolution des multiplicateurs budgétaires dans le temps, ces derniers ne présentant pas de tendance claire. A la lumière de ces résultats, nous concluons que les recommandations de politique économique basées sur des valeurs moyennes des multiplicateurs, devraient prendre en compte la position de l'économie dans le cycle. Par ailleurs, l'effet sur les variables macroéconomiques de chocs de dépenses publiques semblerait plutôt limité au Royaume-Uni dans des périodes non récessives.
\end{abstract}

Mots-clés: chocs de dépenses publiques, mécanisme de transmission budgétaire, modèles à paramètres qui varient dans le temps, cycle économique.

\footnotetext{
Les Documents de travail reflètent les idées personnelles de leurs auteurs et n'expriment pas nécessairement la position de la Banque de France.

Ce document est disponible sur publications.banque-france.fr
} 


\section{INTRODUCTION}

In this paper we investigate if and why government spending multipliers vary across time, taking the example of the United Kingdom over the past fifty years.

In the recent economic history of the UK there have been several moments characterized by intense debates about how changes in government spending may affect the economy. Together with the U.S., the UK was one of the major advanced countries that responded to the financial crisis with a strong counter-cyclical fiscal expansion in 2008. The reversal of the fiscal stimulus in 2010 gave rise to a harsh debate on austerity. Advocates of austerity were of the view that the measures were necessary to ensure the confidence of financial markets about the sustainability of public debt (Rogoff, 2013) and could possibly crowd-in private consumption and investment (Trichet, 2010). Opponents claimed that the program would put at risk the timid recovery and feared large negative effects, arguing that government spending multipliers were particularly large at that moment because of the presence of idle economic resources and of monetary policy being constrained by the zero lower bound (Krugman, 2015).

This paper contributes to the literature on the non-linear effects of fiscal policy by using an econometric framework that is flexible enough to distinguish cyclical variations from structural changes in government spending multipliers and rich enough to discriminate between different theoretical transmission mechanisms.

Economic theory offers a number of reasons why government spending multipliers may vary over time. They can be broadly divided into two groups: cyclical theories and structural theories.

Prominent examples of cyclical theories put forward three main explanations for time variation: economic slack, financial frictions, and the zero lower bound (ZLB) on nominal interest rates. According to the economic slack hypothesis, government spending multipliers should be larger in recessions because government spending can mobilize idle resources without generating inflationary pressures (Michaillat, 2014). The financial friction theory emphasizes access to credit rather than idle resources. Financial frictions impede the access of the private sector to credit. Government spending alleviates these frictions through its stabilizing effect on output (Galí et al., 2007; Canzoneri et al., 2016). The zero lower bound hypothesis posits that at the zero lower bound central banks will not tighten monetary policy to contain inflationary pressures generated by positive fiscal shocks, as they would otherwise. This could create larger multipliers (Christiano et al., 2011; Woodford, 2011; Coenen et al., 2012). 
On the structural side, explanations for time-variation in government spending multipliers include trade openness and the amount of fiscal space, among others. The trade integration theory predicts a downward trend in the size of government spending multipliers, as higher trade integration should increase the share of the government spending impulse that leaks abroad through higher imports. According to the fiscal space theory, government spending multipliers should be larger when governments have more time to stabilize debt after an expansion, i.e., when public debt or the interest rates payments on debt are low (Perotti, 1999; Corsetti et al., 2012; Nickel and Tudyka, 2014).

To shed light on the time-variation of UK government spending multipliers and their drivers, we estimate a time-varying parameter factor augmented vector autoregressive model (TVP-FAVAR) and identify government spending shocks. A TVP-FAVAR has two key advantages, as detailed in Section 2. First, the TVP component of the model is agnostic on whether changes in multipliers are structural or cyclical. Second, the use of factor models allows us to track the responses of a large number of variables and to address the problems of limited information and fiscal foresight, from which many small scale VAR models suffer.

Our results show that UK government spending multipliers vary over time and that most of the variation is cyclical. The multiplier on GDP is typically above one in recessions and below one in expansions. By contrast, multipliers do not exhibit a structural trend. Regarding the different demand components of GDP, the increase of the multiplier in recession is mainly driven by the behavior of investment, which contributes positively in recession, while it responds negatively or negligibly in normal times. The positive effect on consumption is also substantially larger in recession. The amplifying effects of consumption and investment are dampened to some extent by a stronger response of imports, whereas the response of exports does not vary much over time.

As regards the drivers of the cyclical variations, the results of the model are consistent with theories emphasizing the role of financial frictions and economic slack. Typically, a larger impact on output is accompanied by stronger effects on private sector credit generation, suggesting that fiscal expansions help relieving credit constraints. This is in line with the literature that studies the interaction between fiscal multipliers and the financial cycle, which generally finds higher multipliers in period of financial distress (Corsetti et al., 2012; Ferraresi et al., 2015; Borsi, 2018; Pragidis et al., 2018). ${ }^{1}$ As for the economic slack hypothesis, we do find that multipliers are generally larger in recessions.

\footnotetext{
${ }^{1}$ Consistently with this literature, we do not find a significant increase in the UK output multiplier during the recession of the early 90s when measures of financial stress were significantly lower than in the other recession episodes.
} 
However, when investigating inflationary pressures - a variable that has received little attention in the literature on fiscal multipliers - we find only limited evidence for prices to be systematically less sensitive to spending stimuli in recession. Finally, according to our findings, UK multipliers are not systematically higher during the recent zero lower bound period.

As an additional exercise, we then regress the estimated output multiplier on a number of potential cyclical and structural determinants. The results from this regression confirm our previous findings. Credit and financial stress variables have significant impact on the multiplier with the predicted sign. A measure of economic slack and the real policy rate, which captures the degree of monetary policy accommodation, are also significant cyclical drivers of the government spending multiplier. Structural factors are only of second order importance in explaining the variation of the UK multiplier over time.

The rest of the paper is organized as follows: Section 2 details how our paper contributes to the literature. Section 3 presents data and methods. Section 4 presents and discusses the main empirical results of the model while Section 5 focuses on the possible transmission channels and their respective importance for the UK economy. Section 6 presents some robustness exercises, including an analysis of the sensitivity of the results with respect to the identification approach used in the paper. Section 7 concludes. Technical details on the estimation technique and more information on the database are left to the appendix.

\section{Contribution to the Literature}

With regard to the existing literature, this paper makes two contributions. Our first contribution is methodological: we use a TVP-FAVAR framework that allows us to model time variation in a flexible manner and to incorporate large amounts of information. The flexibility of this approach makes it possible to compute fiscal multipliers at each point in time and hence to assess whether multipliers are subject to short term - cyclical variations and/or long term - structural - changes. While other empirical approaches have linked changes in fiscal multipliers to cyclical or structural factors, these questions have been rarely addressed simultaneously. ${ }^{2}$

Local projection methods (Jordà, 2005) are a recent popular approach to study timevariation in fiscal multipliers. This single equation approach allows to compute directly the response of a variable of interest to a (previously identified) fiscal shock. In a nonlinear specification, a transition function links the impulse response to a particular cyclical variable (Auerbach and Gorodnichenko, 2013; Riera-Crichton et al., 2015; Borsi, 2018;

\footnotetext{
${ }^{2}$ Ilzetzki et al. (2013) look at the differential impact of government spending shocks across countries according to key structural and cyclical characteristics in a panel framework.
} 
Dell'Erba et al., 2018; Ramey and Zubairy, 2018) or structural factors (Kim, 2015). Other (non-exhaustive) examples of econometric approaches used to study time-variation in fiscal multipliers include smooth transition vector autoregressive models (STVAR, such as in Auerbach and Gorodnichenko (2012) and Hernàndez de Cos and Moral-Benito (2016)) and threshold autoregressive models (Baum et al., 2012), used to investigate cyclical variations, and rolling regressions, used to investigate structural changes (Cimadomo and Bénassy-Quéré, 2012). ${ }^{3}$

Local projection and STVAR approaches impose ex ante some structure, choosing the variable that drives the transition between states, whether they are of cyclical or structural nature. ${ }^{4}$ Rolling regression approaches are only suited to analyze structural changes. Our framework has the merit of being agnostic on the potential cyclical or structural drivers of time variation in fiscal multipliers, looking only ex-post to possible explanatory factors.

To our knowledge, there are only few papers that employ time-varying parameter models to study fiscal policy questions. These studies, however, are generally limited to the use of small scale time-varying VAR models (Hauptmeier et al., 2010; Cléaud et al., 2013; Rafiq, 2014; Berg, 2015). We innovate in this respect by using a large scale factor model, which has two main advantages. First, it allows us to track the responses of a large number of variables to a government spending shock, including the main components of GDP, as well as price and credit variables. This permits to better assess which channel is most relevant to understand time-variation in UK government spending multipliers. Second, factor models increase the amount of information considered, thereby addressing the limited information problem from which many small scale VARs suffer (Bernanke et al., 2005; Forni and Gambetti, 2014). A special variant of the limited information problem is fiscal foresight (Fragetta and Gasteiger, 2014), i.e., economic agents might have anticipated the increase in government spending. To address the problem of limited information, factor models have been applied to fiscal policy questions by Forni and Gambetti (2010) and Fragetta and Gasteiger (2014). These studies do not allow, however, for time variation.

Regarding our second contribution, our study is one of the few that analyzes timevariation of the spending multiplier in the UK. A large part of the empirical research on time-variation in government spending multipliers has focused on the U.S. (e.g., Auerbach

\footnotetext{
${ }^{3}$ Some recent papers have also studied the heterogeneity in the response of macroeconomic variables with regards to the sign of the fiscal shock during different phases of the business or financial cycle (e.g., Riera-Crichton et al. (2015); Borsi (2018); Pragidis et al. (2018)).

${ }^{4}$ Examples of variables used in this literature to discriminate between states are GDP growth, unemployment, credit growth and the level of government debt.
} 
and Gorodnichenko (2012); Bachmann and Sims (2012); Owyang et al. (2013); Pragidis et al. (2018); Ramey and Zubairy (2018)). ${ }^{5}$

The UK economy is interesting for several reasons. As pointed out above, it is one of the major countries where the debate about fiscal stimulus and austerity was particularly intense in recent years. Second, the UK economy exhibits significant cyclical variations and structural changes over the period considered. It suffered from severe recessions in the 70s and during the last financial crisis, liberalized its financial sector at the beginning of the 80s with the so-called 'Big Bang' reforms, and its public debt displayed large swings. This makes it an interesting case to test different theories.

Among the studies that have analyzed the time-variation of UK government spending multipliers, Cimadomo and Bénassy-Quéré (2012) have employed rolling regressions in a VAR with global factors. They find positive government spending multipliers in the 70s and 2000s but insignificant multipliers in the 80s and 90s. According to their analysis this is mainly due to several important structural changes occurred in the economy over these two decades. Differently from them, our results do not suggest that UK government spending multipliers incurred significant structural changes over this period, the high value of the output multiplier in the 70s and 2000s being largely explained by the three recession episodes occurred in these two decades. Using a threshold VAR, Baum et al. (2012) find that UK spending multipliers are small, both with positive and with negative output gaps. Rafiq (2014) uses a small scale Bayesian time-varying VAR model to study UK government spending multipliers and performs a two-stage regression to look at possible driving factors of time variation. He finds support for the fact that government multipliers are larger in recessions than in expansion periods and that credit and financial factors as well as government solvency issues are important to explain time variation. Our findings are broadly consistent with his results but our modeling choice allows us to look at the response of a wider set of variables and to perform multipliers for several aggregate demand variables, hence refining the analysis of the mechanisms behind the variation of UK fiscal multipliers.

\footnotetext{
${ }^{5}$ For other countries' evidence see, among others, Berg (2015) for Germany, Cléaud et al. (2013) for France, Hernàndez de Cos and Moral-Benito (2016) for Spain, Hauptmeier et al. (2010) for the euro area, Owyang et al. (2013) for Canada and Mineshima et al. (2014) for six G7 countries. Almeida et al. (2013) look at the effect of fiscal consolidations in a small euro area economy. Gechert (2015) and Gechert and Rannenberg (2018) perform interesting meta-regression analyses on about 100 studies covering a large set of countries.
} 


\section{Data And Methods}

3.1. Data. The time series used to estimate the TVP-FAVAR model have been downloaded from Thomson Reuters Datastream, which contains data from different national and international sources, and cover the period from 1960 to 2015, at quarterly frequency. The data set includes a total of about eighty UK time series, ranging from standard macroeconomic time series (output and its components, employment series, production indexes, inflation measures, etc.), financial time series (effective exchange rates, interest rates on loans and deposits, stock prices, etc.) and time series of governmental expenditure. In particular, the variable used to identify fiscal shocks is the final consumption expenditure of the general government, at constant prices, from the UK Office for National Statistics (ONS). The output variable used to compute the fiscal output multiplier is the gross domestic product at constant prices, also from the ONS. The appendix provides details of each series along with classification codes and details on the series' transformation to ensure stationarity.

3.2. The TVP-FAVAR model. The time-varying parameter factor augmented vector autoregressive model (TVP-FAVAR) used in this paper closely follows Koop and Korobilis (2010) and Korobilis (2013) and the description here is kept relatively short.

In general, FAVAR models are a hybrid between dynamic factor models (DFM) and the standard structural vector autoregressive (SVAR) model: a joint VAR is specified for some factors $f_{t}[k \times 1]$ that are extracted from a large panel of time series $X_{t}\left[n_{x} \times 1\right]$ and some observable policy variables $y_{t}\left[n_{y} \times 1\right]$. Factor models allow working with high dimensional data, as the approach extracts the common dynamics from a wide set of time series $X_{t}$. The FAVAR Model consists of a state and an observation equation.

The FAVAR state equation describes the joint dynamics of the factors $f_{t}$ and the observable policy variables $y_{t}$. This system of equations is capturing the main dynamics of the economy and is modelled as a VAR:

$$
\begin{gathered}
\left(I-\Phi_{t}(L)\right)\left[\begin{array}{l}
f_{t} \\
y_{t}
\end{array}\right]=u_{t} \\
u_{t} \sim N\left(0, \Omega_{t}^{u}\right)
\end{gathered}
$$

where $u_{t}$ is the time $t$ reduced form shock. The error term $u_{t}$ has mean zero and a variancecovariance matrix $\Omega_{t}^{u}$. $\Phi_{t}(L)$ is a matrix polynomial of order $p$. Both the regression coefficients as well as the covariance are allowed to vary over time.

The observation equation specifies the relationship between the individual time series $X_{t}$ and the vector of the variables of the state equation. Specifically, $X_{t}$ depends on the 
state vector $\left[f_{t}, y_{t}\right]$ and an idiosyncratic component $e_{t}$ :

$$
\begin{gathered}
X_{t}=\left[\begin{array}{ll}
\Lambda^{f} & \Lambda^{y}
\end{array}\right]\left[\begin{array}{l}
f_{t} \\
y_{t}
\end{array}\right]+e_{t} \\
e_{t} \sim N\left(0, \Omega^{e}\right) \\
\Omega_{t}^{e}=\operatorname{diag}\left(\left(\omega_{1}^{e}\right)^{2}, \ldots,\left(\omega_{n_{x}}^{e}\right)^{2}\right)
\end{gathered}
$$

where $\Lambda^{f}\left[n_{x} \times k\right]$ denotes the matrix of factor loadings of the factors $f_{t}$ and $\lambda^{y}\left[n_{x} \times n_{y}\right]$ the matrix of the parameters of the observable variables $y_{t}$. The error term $e_{t}$ has mean zero and a variance-covariance matrix $\Omega^{e}$, which is assumed to be diagonal.

Note that the time variation in the model is restricted to the FAVAR state equation, i.e to the relationship between the common factors driving the economy. Since the observation equation of the FAVAR model does not feature any time-varying parameters, a two step estimation method as in Korobilis (2013) can be employed to estimate the factors and their loadings. ${ }^{6}$

The modeling of time variation in the state equation follows the specifications employed for time-varying structural VARs (Primiceri, 2005; Del Negro and Primiceri, 2015). In particular, we allow for time variation in the regression coefficients $\tilde{\Phi}_{t}$ and in the covariance matrix $\Omega_{t}^{u}$. The covariance matrix is thereby decomposed into diagonal and off-diagonal elements

$$
\Omega_{t}^{u}=A_{t}^{-1} \Sigma_{t}\left(A_{t}^{-1} \Sigma_{t}\right)^{\prime}
$$

where $\Sigma_{t}=\operatorname{diag}\left(\sigma_{1, t}, \ldots, \sigma_{k+n_{y}, t}\right)$ and $A_{t}$ is a lower triangular matrix with ones on the main diagonal and elements $a_{(i, j), t}$ on the off-diagonal elements.

We stack the dynamic system given in equation (1) into the matrices $\tilde{\Phi}_{t}=\left(\phi_{1, t}^{\prime}, \ldots, \phi_{p, t}^{\prime}\right)$, where $\phi_{i, t}^{\prime} \forall i \in\{1, \ldots, p\}$ represents the vector of coefficients of the $i$ 's equation in (1), $\tilde{a}_{t}=\left(a_{(i, 1), t}^{\prime}, \ldots, a_{(i, i-1), t}^{\prime}\right) \forall i \in\left\{1, \ldots, k+n_{y}\right\}, \tilde{\sigma}_{t}=\left(\log \left(\sigma_{1, t}\right), \ldots, \log \left(\sigma_{k+n_{y}, t}\right)\right)$, and assume that the drifting parameters $\left(\tilde{\Phi}_{t}, \tilde{a}_{t}\right.$ and $\left.\tilde{\sigma}_{t}\right)$ follow independent random walks:

$$
\left.\begin{array}{rl}
x_{t} & =x_{t-1}+\epsilon_{t}^{x} \\
\epsilon_{t}^{x} & \sim N\left(0, Q_{x}\right)
\end{array}\right\} \quad \forall x \in\{\tilde{\Phi}, \tilde{a}, \tilde{\sigma}\}
$$

where $\epsilon_{t}^{x} \forall x \in\{\Phi, \tilde{a}, \tilde{\sigma}\}$ represent innovation vectors for the associated parameter vectors. We impose that the matrix $Q_{\tilde{a}}$ is block-diagonal, where each block consists of the coefficients $a_{(i, j), t}$ which are in the same row as in $A_{t}$.

\footnotetext{
${ }^{6}$ In the paper we only consider constant factor loadings. See also Korobilis (2009), the working paper version of Korobilis (2013), who finds that the strongest evidence for the parameters to vary over time applies to the dynamic equation (1), while the parameters in the observation equation (3) show only a modest amount of variation over time.
} 
3.3. Estimation. Following Korobilis (2013) the FAVAR model is estimated using a twostep procedure. In the first step, the common components of $\xi_{t}=\left[\begin{array}{ll}f_{t}^{\prime} & y_{t}^{\prime}\end{array}\right]^{\prime}$, are determined and the static observation equation is estimated. In a second step, the dynamic state equation is estimated, treating the factors as observed variables. ${ }^{7}$ We model timevarying relationships between the common components using the techniques developed for time-varying VARs. While it is possible to estimate dynamic factor models with one step estimators, using likelihood-based or Bayesian techniques, such estimations become quickly computationally demanding if the cross-section is large or parameters are timevarying. ${ }^{8}$

To estimate the FAVAR model we choose two factors according to the Bai and $\mathrm{Ng}$ (2002) information criterion $\mathrm{BIC}_{3}$ (notation as in Bai and $\mathrm{Ng}(2002)$ ) to the sample covariance matrix of $X_{t}$. The factors are estimated using the first $k=2$ principal components of $X_{t}$. The variable considered in the vector of the policy variables $y_{t}$ is government consumption expenditure. Hence $y_{t}$ is a scalar and the state equation of the model is three-dimensional. We choose a lag length of one in the state equation, to have a parsimonious lag structure for the time-varying model. ${ }^{9}$

In the observation equation (3) there are $n_{x}$ independent equations, so we can sample the parameter matrices $\Lambda^{f}$ and $\Lambda^{y}$ equation-by-equation. We use uninformative priors.

In the state equation (1) all time-varying parameters are sampled sequentially using the Gibbs sampler. Sequentially, we draw sequentially the time varying coefficients $\left(\tilde{\Phi}^{T}\right)$, the simultaneous relations $\left(A^{T}\right)$, the volatilities $\left(\Sigma^{T}\right)$ and the hyperparameters $\left(Q_{\tilde{\Phi}}, Q_{\tilde{a}}\right.$, $\left.Q_{\tilde{\sigma}}\right)$, in each case conditional on the observation and all other parameters. As Cogley and Sargent (2002, 2005); Primiceri (2005); Del Negro and Primiceri (2015) and Canova et al. (2007) we enforce stationarity by rejecting unstable draws.

Following the literature, we set informative priors for the regression coefficients $\Phi_{0}$ and the covariance matrix $\Omega_{0}$ in the initial period, as well as for the hyperparameters $Q_{x}$ that determine the variance of the drift of the parameters. The priors are set on the basis of a training sample from 1960:Q1 to 1965:Q4. Details can be found in the appendix.

We burn the first 2 million draws of the iterations and then take every 40th draw. We introduce multiple checks to ensure that the algorithm has converged. First, we run

\footnotetext{
${ }^{7}$ Bai and $\mathrm{Ng}$ (2006) show in a frequentist setting that factors estimated via principal components can be treated as observed, if the panel is sufficiently large in both dimensions.

${ }^{8}$ Bates et al. (2013) show that the principal components estimator remains consistent in models with parameter variation if the variation is not too large.

${ }^{9}$ Time-varying model quickly run into problems with overparametrization. This is why most of the literature chooses few lags (see for instance Korobilis (2013) and Amir-Ahmadi et al. (2015) and the references therein).
} 
the algorithm for multiple initial random seed numbers and starting values. Second, we calculate the autocorrelation of the draws and inefficiency factors as in Geweke (1992). We conclude that our results are not subject to convergence problems. Details about the convergence statistics are reported in the appendix.

3.4. Identification. Our identification of the government spending shock applies the scheme of Blanchard and Perotti (2002) using methods developed for dynamic factor and FAVAR models (Stock and Watson, 2016).

The observation and state equation of the FAVAR system can be unified into the following joint expression:

$$
\begin{aligned}
X_{t}^{1} & =\Lambda^{1}\left[\Phi(L) \xi_{t}+u_{t}\right]+e_{t}^{1} \\
& =\Lambda^{1} \Phi(L) \xi_{t}+\Lambda^{1} u_{t}+e_{t}^{1}
\end{aligned}
$$

where $X_{t}^{1}$ are the first $k+n_{y}$ variables of the time series panel (in our case $k+n_{y}=3$ ). The extended error term $\hat{u}_{t}:=\Lambda^{1} u_{t}$ has the following statistical properties: $\hat{u}_{t} \sim N\left(0, \hat{\Omega}_{t}^{u}\right)$ with $\hat{\Omega}_{t}^{u}:=\Lambda^{1} \Omega_{t}^{u}\left(\Lambda^{1}\right)^{\prime}$. We proceed by taking the Cholesky decomposition of the variancecovariance matrix of the extended error term $\hat{u}_{t}$ :

$$
\hat{\Omega}_{t}^{u}=H_{t} \cdot H_{t}^{\prime}
$$

which implies that the structural error term $\epsilon_{t}$ is given by:

$$
\epsilon_{t}:=H_{t}^{-1} \cdot \hat{u}_{t}=H_{t}^{-1} \cdot \Lambda^{1} u_{t}
$$

where the structural errors are orthonormal $E\left[\epsilon_{t} \epsilon_{t}^{\prime}\right]=I$.

In our identification scheme government spending is the last (i.e., $k+n_{y}$ th) variable of the vector $X_{t}^{1}$. Since $H_{t}$ is a lower-triangular matrix by construction, the identification assumption implied by the ordering of the variables in $X_{t}^{1}$ is that the government does not respond contemporaneously to macroeconomic shocks because of delays in decisionmaking (Blanchard and Perotti, 2002). In our baseline case $X_{t}^{1}$ consists of the following variables: private household consumption expenditure, total investment, and government consumption expenditure, all in real terms; and we impose that government spending does not contemporaneously respond to variation in private consumption and investment.

The Blanchard and Perotti (2002) identification scheme has been criticized. In particular, it has been argued that this strategy may be subject to endogeneity issues and identified shocks may be forecastable to a significant degree, failing to capture the true effect of unanticipated changes in public expenditure (Ramey, 2011). This "nonfundamentalness" problem is well recognized to be particularly relevant for fiscal shocks. 
As factor models are a way to address the problem of fiscal foresight by extracting the information of a large informational set (Fragetta and Gasteiger, 2014), we believe that the critique of the Blanchard-Perotti approach that applies to small scale VARs is less relevant in our case. Furthermore, we conduct several robustness checks with regards to our identification strategy. A first set of checks is done within the Blanchard-Perotti framework. The Blanchard-Perotti assumption is that government spending does not respond contemporaneously to "all other variables" in the VAR (i.e., it is ordered last). Compared to the standard VAR, an advantage of the FAVAR approach is that we can vary "all other variables" and estimate a number of variants of the Blanchard-Perotti approach within the same information set. This is because, differently from standard VARs, the number of macroeconomic shocks in factor augmented VARs and structural dynamic factor models is significantly smaller than the number of endogenous variables (see Stock and Watson (2016)). Second, we compare our results with those obtained using an alternative identification scheme based on sign restrictions, similar to those proposed in Forni and Gambetti (2010). Results for these different approaches are presented in the robustness section 6 .

In addition, narrative methods based on military spending news have been proposed to estimate US fiscal multipliers (Barro and Redlick, 2011; Ramey, 2011; Owyang et al., 2013; Ramey and Zubairy, 2018). To our knowledge the narrative method has been applied to the UK only on tax changes (Cloyne, 2013). Constructing a direct measure of spending shocks for the UK from variations in defense spending would require a sizeable archive work and the use of historical data (most of the action in defense spending occurred before the 1970s), which is beyond the scope of this paper. Furthermore, as discussed in Ramey (2018), and contrary to earlier findings, the Blanchard-Perotti identification approach does not produce per se different multipliers compared to narrative methods. Observed differences in the results are mainly driven by the way multipliers are computed. ${ }^{10}$

3.5. Definition of government spending multipliers. We report cumulative multipliers defined as the cumulated response of output (or any other economic variable of interest) in response to a cumulated increase in government spending that amounts to one percent of GDP. ${ }^{11}$

\footnotetext{
${ }^{10} \mathrm{By}$ using cumulative multipliers and avoiding a constant conversion factor, as explained in the next section, we address the problems that papers relying on the Blanchard-Perotti approach often display, as explained in Ramey (2018).

${ }^{11}$ Cumulative multipliers (or, alternatively present value multipliers), by taking into account the ratio of the integral of the impulse response of output to the integral of the impulse response of government spending, are considered the policy-relevant multipliers (Ramey, 2018).
} 
More technically, the cumulative multiplier is defined as follows:

$$
\mathcal{C M}_{\mathcal{P} \mid t}=\frac{\sum_{j=1}^{\mathcal{P}} x_{j}\left(\Xi_{t}\right)}{\sum_{j=1}^{\mathcal{P}} g_{j}\left(\Xi_{t}\right)} \cdot \frac{1}{\mu_{t}}
$$

where $x_{k}\left(\Xi_{t}\right)$ denotes the output response, that is, the impulse response function at horizon $k$ in period $t, g_{k}\left(\Xi_{t}\right)$ the corresponding government spending response, and $\Xi_{t}$ comprises all coefficients and variance-covariance matrix estimates of the TVP-FAVAR model as of time $t .1 / \mu_{t}$ is the so-called conversion factor (Ramey, 2018): because the share of government spending with respect to GDP $\left(\mu_{t}\right)$ varies over time we need to rescale the impulse responses of output (in percent) to a government spending shock (in percent) by the inverse of the government spending share.

In the rest of the paper, we report government spending multipliers over two years $(\mathcal{P}=8)$, but our results are robust to alternative horizons.

\section{Time Variation in UK Government Spending Multipliers}

This section shows evidence that the effects of government spending shocks on output and its main aggregate components vary over time. We look at government spending multipliers at two-year horizons over the sample from 1966:Q1 to 2015:Q4. For the same set of key variables, we also show the impulse response functions averaged over the full sample as well as for specific dates of interest.

4.1. Time-varying government spending multipliers. Figure 1 shows cumulative government spending multipliers over two years for output and its main aggregate components (private consumption, total investment, imports and exports, all in real values). The cumulative multipliers for the GDP deflator and for a measure of credit to the private sector (including both nominal credit to households and to non-financial corporates, divided by the GDP deflator) are also displayed. These two responses will be useful for our discussion on the transmission mechanisms in Section $5 .^{12}$

In each graph, the solid line refers to the median of the posterior distribution of the impulse response functions and the gray shaded area represents the 68 percent error bands. The gray bars indicate recessions, defined as at least two consecutive quarters of negative GDP growth.

Figure 1 highlights some important insights:

\footnotetext{
${ }^{12}$ When computing impulse response functions, we keep coefficients constant, as is standard in the literature (Primiceri, 2005). The coefficient should therefore be interpreted as the response of the variable of interest, if no other shock (than to government spending) occurs in the system (e.g., other shock to variables or coefficients).
} 
FIGURE 1. Government spending multipliers

The figure shows 2-year cumulative government spending multipliers for output, private consumption, investment, imports, exports, the GDP deflator and a measure of credit to the private sector. In each case, the solid lines refer to the median of the posterior distribution of the impulse response functions and the gray shaded area represents the 68 percent error band of the posterior distribution. The dotted line indicates the unity-line. The gray bars indicate recession episodes where recessions are defined of at least two consecutive quarters of negative GDP growth.
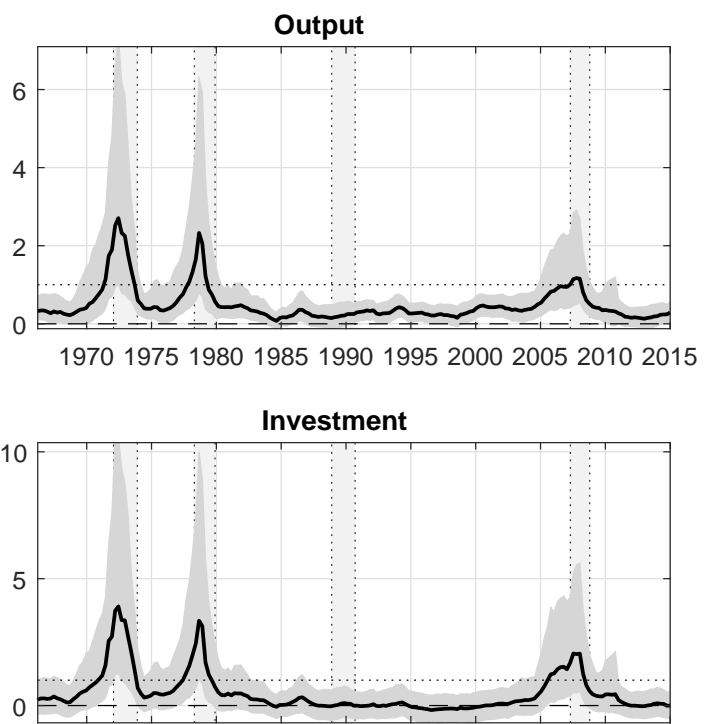

1970197519801985199019952000200520102015
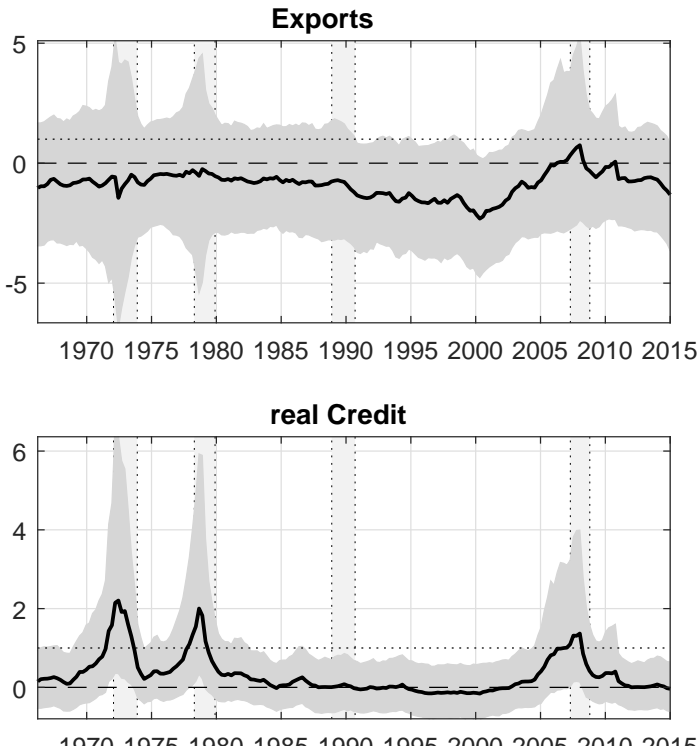

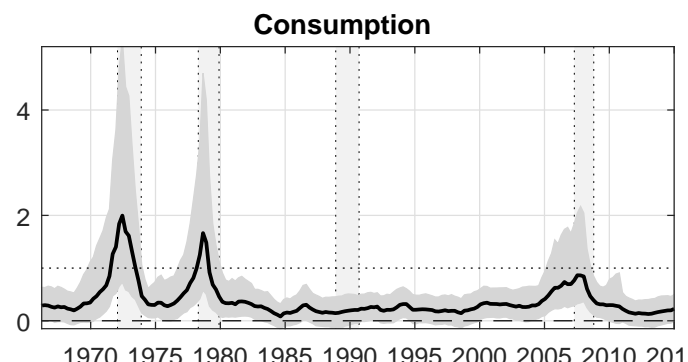

Imports

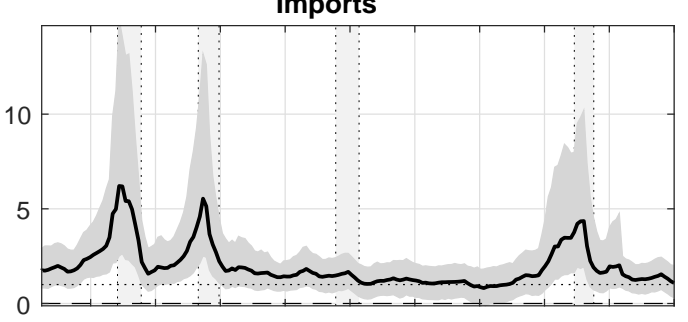

1970197519801985199019952000200520102015

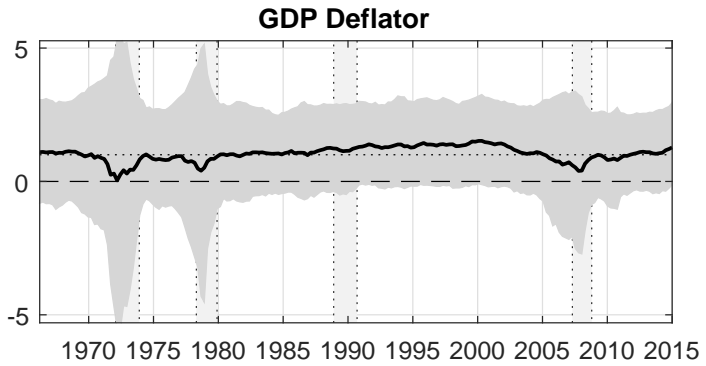


(1) The government spending multiplier for output shows a significant degree of variation over time and most of that variation is cyclical. In general, during and around recession episodes, the multipliers tend to increase in size. An exception is the recession of the early 90s, where no increase in the value of multipliers is observed (see Section 5 for more details).

(2) A model specification based on the assumption of constant coefficients would imply a misspecification. The average value of the multiplier over the sample is clearly below one (0.48), suggesting substantial crowding out effects. However, it is important to differentiate between recessions, where the average multiplier is above one (1.21), and non-recession periods, where the average multiplier is below one (0.35).

(3) The cyclical variation of the output multiplier is driven by private consumption and investment, whereas imports moderate the variation. The time profile of the multipliers of consumption and investment display a qualitatively similar pattern and are larger in recessions. In line with its general business cycle properties, the amplitudes of the swings of the multiplier for investment are larger. It is on average close to zero in expansionary periods, suggesting the existence of crowding-out effects. In recession, however, it is clearly above one. The multiplier for consumption is positive over the entire sample, consistent with Galí et al. (2007).

The multiplier for imports is positive and statistically significant over the entire sample, consistent with the idea that part of a fiscal stimulus leaks abroad, as higher output increases the demand for imports. The reaction of imports is stronger in recessions, in line with the stronger response of output and hence higher import demand. This moderates the expansionary effect of fiscal policy on output. The exports multiplier, by contrast, is stable and close to zero over the entire sample. This result is consistent with the view that, in a small open economy, exports depend mainly on exogenous foreign demand.

(4) There is no evidence of structural changes in the size of multipliers. First, there is no visible trend. Second, and more formally, we assess the long-term pattern of the fiscal spending multiplier by testing for multiple breaks at unknown points in the sample (see Glocker and Wegmüller (2018), based on (Bai and Perron, 1998, 2003)). ${ }^{13}$ We find no evidence for structural breaks at the 10 percent level.

Averaging across decades, the two-year cumulative government spending multiplier for output has an average value of 1.03 in the $1970 \mathrm{~s}, 0.32$ in the $1980 \mathrm{~s}, 0.26$ in the $1990 \mathrm{~s}$, and 0.45 in the rest of the sample. The decrease in the magnitude of the multiplier from the 1970s to the 1980s has been documented also by other studies, see in particular Cimadomo

\footnotetext{
${ }^{13}$ More specifically, we regress the change of the fiscal spending multiplier of GDP on a constant term and control for autocorrelation and/or heteroskedasticity in the residuals.
} 
and Bénassy-Quéré (2012) that attribute it to structural changes in the economy. What our results highlight however, is that the higher value of the GDP multipliers in the 1970s is primarily due to the two severe recessions that occurred in this decade, in other words by short term effects that raised the average value of the multiplier for the whole decade, rather than to structural changes. ${ }^{14}$

4.2. Impulse response functions. Figure 2 shows the impulse response functions (IRFs) to a government expenditure shock for the same set of variables shown in section 4.1 over the first 8 years (32 quarters). The previous subsection focused on multipliers over a twoyear horizon, whereas Figure 2 allows us to investigate whether the effects vary across different horizons, i.e., whether persistence is affected. The black line in each graph is the median of the posterior distribution and the dotted lines the 68 percent error band of the posterior distribution. ${ }^{15}$

The charts in the first row show the average impulse response functions over the whole period from 1966:Q1 to 2015:Q4. Overall, the results for the full sample are consistent with the constant coefficient VAR literature (see, for instance, Blanchard and Perotti (2002), Galí et al. (2007) and Mountford and Uhlig (2009)). There is a persistent increase in output. Consumption and investment also respond positively, with consumption reacting weaker and investment reacting stronger than output. In line with the more volatile nature of investment, the response is less persistent than the response of consumption. A part of the fiscal stimulus spills to foreign countries, as the response of imports is positive and highly persistent. ${ }^{16}$

Rows 2 to 6 of Figure 2 show the impulse response functions for some selected years, corresponding to different phases of the UK business cycle. In light of the results in the previous section, we report three out of the four recessions experienced by the UK economy over the sample: $1974^{17}, 1990$ and 2008. We also look at two non-recession years:

\footnotetext{
${ }^{14}$ In the appendix, we show that a rolling regression approach might lead to misleading inference about the spending multiplier.

${ }^{15}$ For ease of presentation, the size of the shock is normalized to one percent increase in government spending at impact.

${ }^{16}$ The response of exports, which we do not report here to save space, is small in magnitude and not significantly different from zero over the entire horizon at all times.

${ }^{17}$ Results for the 1979 recession episode are quantitatively similar to those of 1974 .
} 
FiguRE 2. Impulse response functions

The figure reports the impulse response functions to a one percent increase in government spending. The impulse response functions are shown for a horizon of up to 32 quarters (8 years). The first row shows the average responses for the full sample going from 1966 to 2015; the remaining rows show the responses for selected years (averaged over Q1 to Q4), corresponding to different phases of the UK business cycle.
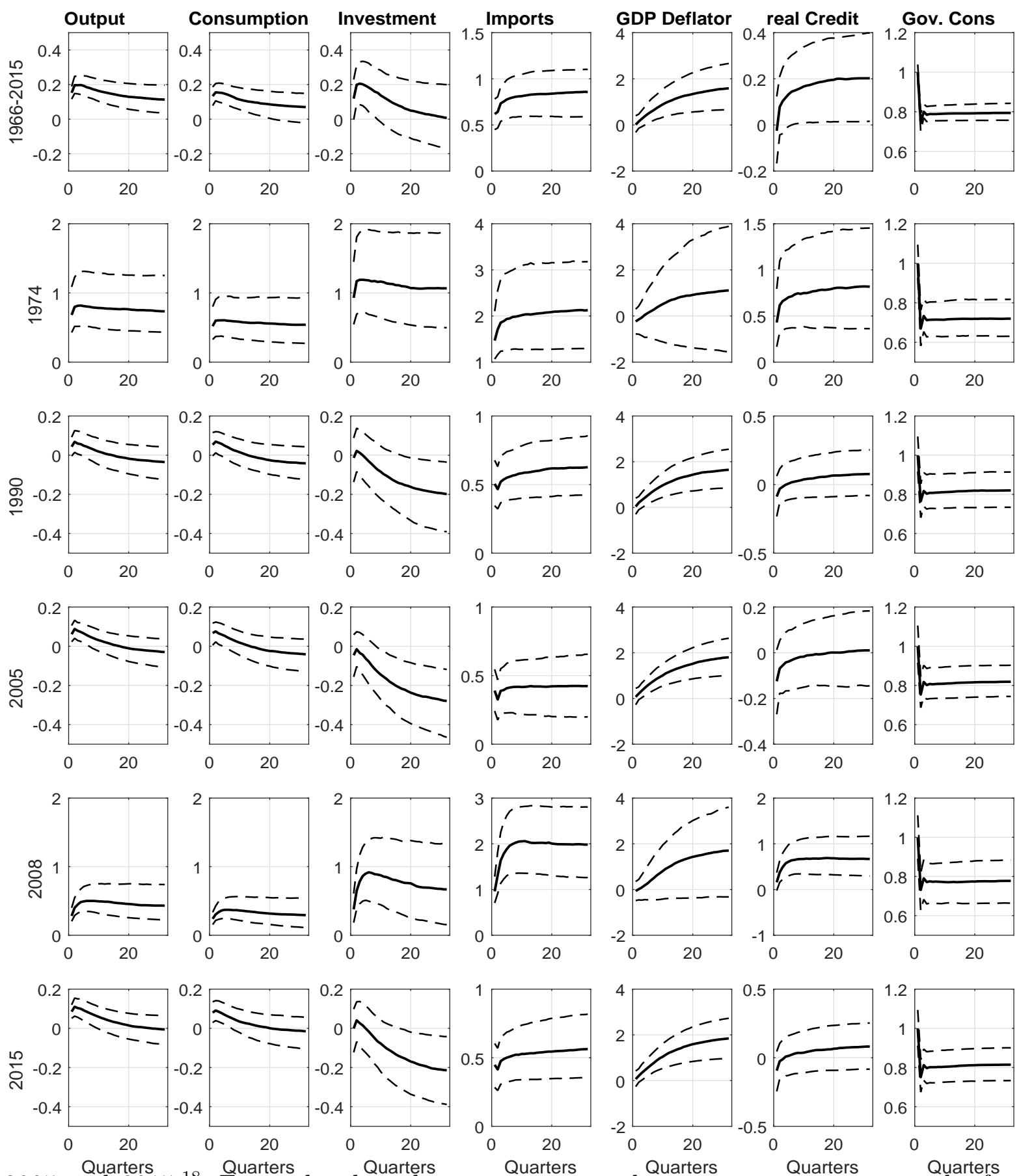

2005 and 2015. ${ }^{18}$ For each selected year, we report the average response over the four quarters.

${ }^{18}$ The choice of the expansionary years is somewhat arbitrary. We choose to look at two years when economic and financial conditions were broadly favorable (robust real GDP growth, low financial stress) 
The response of government spending to its own shock follows a similar pattern at all dates. This shows that the variation in the response of GDP and its components is not driven by a variation in the persistence of the government shock.

Consistently with what we have seen in Figure 1, the effects on output are particularly strong in recessionary years 1974 and 2008, whereas they are much weaker in the years 2005 and 2015. Additionally Figure 1 shows that the effects of government spending shocks are not only stronger in recession, but also more persistent. In the two selected expansionary years, output returns to its pre-shock path relatively quickly, while in the two recessionary periods, output stays above its pre-shock path for the entire horizon considered. As regards the components of demand, the observed pattern is driven by consumption and investment. In 1974 and 2008 the effect on investment is large and persistent, whereas in 2005 and 2015, the response is insignificant on impact and turns negative over the medium term. The negative medium term response is consistent with the idea that there are strong crowding out effects for investment in normal times. The initial response of consumption is positive both in recessions and expansions, but in expansions the reaction is more short-lived and turns statistically insignificant after about two years.

Finally, the response of output in 1990 is different from the other recessions and resembles the response of the expansionary years. This suggests that the government multiplier does not increase automatically in every recession. The next section analyzes the drivers of time-variation and treats in more detail the case of the 1990 recession.

\section{THE TRANSMISSION MECHANISM}

\subsection{Determinants of spending multipliers - Theory and Data. Economic theory} offers three main reasons why the government spending multiplier of output may vary over time in a cyclical manner: the existence of financial frictions, the presence of economic slack, and monetary policy being constrained at the zero lower bound. A series of structural determinants may also influence the size and evolution of multipliers. Such hypotheses can be tested by regressing the estimated series of government spending multiplier for output described in section 4.1 on a set of plausible theory-based explanatory variables (results are presented in section 5.2).

According to the financial frictions hypothesis, private sector's access to financial markets decreases when financial frictions increase. Financial cycles have been found to be but that differ along one interesting dimension, the stance of monetary policy. In particular, in 2015 monetary policy was still at the ZLB, whereas it was unconstrained in 2005. As can be seen from Figure 1 , the output multiplier in expansionary years does not fluctuate substantially, so that results for other expansionary years would be expected to be similar. 
on average longer and ampler than normal business cycles (Borio, 2014) and the severity of recessions of financial nature higher than that of non-financial recessions (Jordà et al., 2013). In financial downturns, government spending interventions may have stabilizing effects on output by alleviating financial frictions. This mechanism is modeled for instance in Canzoneri et al. (2016). Because of financial distress, the share of households with limited asset market participation is high, leading to a higher economy-wide marginal propensity to consume and a larger spending multiplier. A similar mechanism is described in Galí et al. (2007), where a higher share of liquidity constrained agents increases government spending multipliers. To measure the share of credit-constrained agents, we construct a measure of credit impulse, defined as the year-on-year change in private sector credit relative to GDP. To measure UK financial market stress we use the indicator proposed by Duprey et al. (2017). ${ }^{19}$

According to the economic slack hypothesis, government spending multipliers should be larger in recessions, because of the existence of idle resources in the economy that government spending can mobilize without generating inflationary pressures. In a boom, by contrast, the economy is at full capacity and resources are scarce (Michaillat, 2014). We measure the amount of slack with the output gap, as estimated by the OECD. These statedependent effects may be also augmented by second round effects through the response of monetary policy. In normal times monetary policy responds to inflationary government spending shocks by increasing policy rates. On the contrary, the stimulus in recession brings about much smaller inflationary effects as the economy is operating at low capacity, reducing the need for monetary authority to react. As a proxy for the monetary stance we use the short-term real rate computed as the difference between the policy rate and the contemporaneous inflation rate.

Recent papers have also studied the effect of fiscal policy when monetary policy is at the zero lower bound, mostly in a DSGE framework (Eggertsson, 2011; Christiano et al., 2011; Woodford, 2011; Coenen et al., 2012). According to these papers, the central bank will not respond to a government spending shock at the zero lower bound, generating larger multipliers. The evidence on fiscal multipliers at the ZLB is, however, mixed since other papers suggest that the ZLB is not a sufficient condition per se to have higher average multipliers (Swanson and Williams, 2014; Bredemeier et al., 2015; Debortoli et al., 2018; Li and Tian, 2018). ${ }^{20}$ In the regression presented in the next section, we include a ZLB

\footnotetext{
${ }^{19}$ Their measure of financial market stress is based upon a composite index involving data on three financial market segments: (i) equity markets, (ii) bond markets, and (iii) foreign exchange markets.

${ }^{20}$ The main arguments put forward by this literature are: i) non-conventional monetary policy and conventional monetary policy are perfect substitutes; ii) medium and long-term interest rates, which
} 
dummy set to one from 2009:Q1 onwards, date at which the UK policy rate reached the floor of $0.5 \%$.

Turning to structural determinants of fiscal multipliers, standard open-economy versions of the IS-LM model argue that the size of the spending multiplier depends, inter alia, on two structural factors: (1) the propensity to save and (2) the degree of trade openness. In particular, comparative statistics suggest that when these factors are low, leaks are small and multipliers are large. We measure these determinants by means of the household saving ratio and the import ratio (imports/GDP). ${ }^{21}$

Finally, the degree of fiscal space is another factor that has received attention in the literature of government spending multipliers. Some studies find that the overall cumulative effect of a spending shock on real GDP is positive and significant at moderate debt-toGDP ratios, but null or negative as the ratio increases (Corsetti et al., 2012; Ilzetzki et al., 2013; Nickel and Tudyka, 2014). When public debt costs are high, Ricardian agents expect that the fiscal consolidation that follows a fiscal stimulus is imminent. Accordingly, they will spend less and save more than in the case in which public debt costs are low. We use interest payments on public debt over GDP as a proxy for fiscal space in our empirical investigation.

\subsection{Which factors drive the variation of UK government spending multipliers?}

Results in Figures 1 and 2 give a first insight about which transmission channels may be important in explaining the cyclical variation of UK government spending multipliers.

Our findings largely corroborate the financial frictions theory predictions. The multiplier for credit displays a strong business cycle dependency. Large effects of government spending shocks on economic activity are accompanied by large effects on credit to the private sector, suggesting that fiscal expansions in periods of financial stress relieve credit constraints to the private sector. This seems not to be true for all recessions, as the results for the 1990/91 UK recession suggest. Indeed, it is worth noting that this recession has not been accompanied by a banking crisis according to the Reinhart and Rogoff (2011) classification, differently from those started in 1974 and 2007, supporting the idea of Jordà et al. (2013) that recessions of financial nature are different.

are more relevant for investment and consumption decisions, are usually not constrained at zero; iii) private agents anticipate future government spending reversals following a positive spending shock; this discourages current private consumption due to the anticipation of a future increase in the long-run real interest rate.

${ }^{21}$ Standard open-economy theory, such as the Mundell-Fleming model, also predicts that government spending multiplier should be larger under a fixed exchange rate regime. We do not explore this channel since the UK economy has a flexible exchange rate regime for most of the sample period. 
We find mixed evidence for theories that emphasize the role of economic slack. Our results confirm that multipliers are generally larger in most recessions, in line with this literature. When we investigate whether the inflationary pressures that arise because of higher government spending are smaller in recessions-something that is neglected by most of existing papers on time-varying multipliers - we do find some evidence for somewhat smaller responses of inflation in recessions, although this evidence is weak (as suggested by the wide confidence bands in Figure 1). ${ }^{22}$

Finally, the results do not support prima facie the notion that the government spending multipliers are larger at the zero lower bound. The output spending multiplier in the Great Recession of 2008 is smaller than in the recessions of the $70 \mathrm{~s}$, where interest rates were further away from zero. Furthermore, we do not find evidence of significant differences in the response of aggregate demand components in the two selected expansionary years 2005 and 2015, suggesting that the effect of UK government spending shocks are not systematically higher in periods in which policy rates are constrained at the ZLB.

In what follows we will test empirically the relevance of different transmission channels for the UK economy in a more rigorous way. We use a linear regression analysis carried out over the sample from 1970:Q1 to 2015:Q4. To account for measurement uncertainty in the multiplier, we use a Bayesian approach. More specifically, we run separate regressions for each draw of the spending multiplier. This procedure allows us to account for two sources of uncertainty, one stemming from estimation uncertainty of the coefficients in the regression, the other from the fact that the dependent variable is estimated and hence prone to measurement errors. ${ }^{23}$ The regression equation takes the following form:

$$
y_{t}=\alpha y_{t-1}+\boldsymbol{\beta}^{\prime} \mathbf{x}_{t-1}+\epsilon_{t}
$$

The dependent variable $y_{t}$ is the two-year cumulative output multiplier presented in Figure 1. $\mathbf{x}_{t-1}$ is the vector of explanatory variables described in the previous section and shown in Figure 3. We use lagged values of the regressors to address the problem of reverse causation from the output multiplier to the business cycle. We also include a ZLB dummy, a constant term, and a linear time trend. We include a lagged dependent variable $y_{t-1}$ to account for persistency in the multiplier and serial correlation in the residuals. Table 1 reports the long-run impact of the regressors on the UK cumulative output multiplier,

\footnotetext{
${ }^{22}$ Or in other words, we cannot reject the null that the inflation response to government spending shocks does not change in recessions, but this may also be a result of high uncertainty (low power).

${ }^{23}$ Regarding the priors, we do not introduce out of sample information and use uninformative priors. The regression equation is estimated using a Gibbs sampling algorithm with 5,100 draws dropping the first 100 draws (see Geweke (1993) for details).
} 
defined as $\tilde{\boldsymbol{\beta}}=\boldsymbol{\beta} /(1-\alpha)$. The point estimates of the regression coefficients are the median of the corresponding posterior distribution. The median of the Durbin-Watson statistic and adjusted $R^{2}$ are also reported.

FiguRE 3. Explanatory variables

Variables used in the Bayesian linear regression (12).
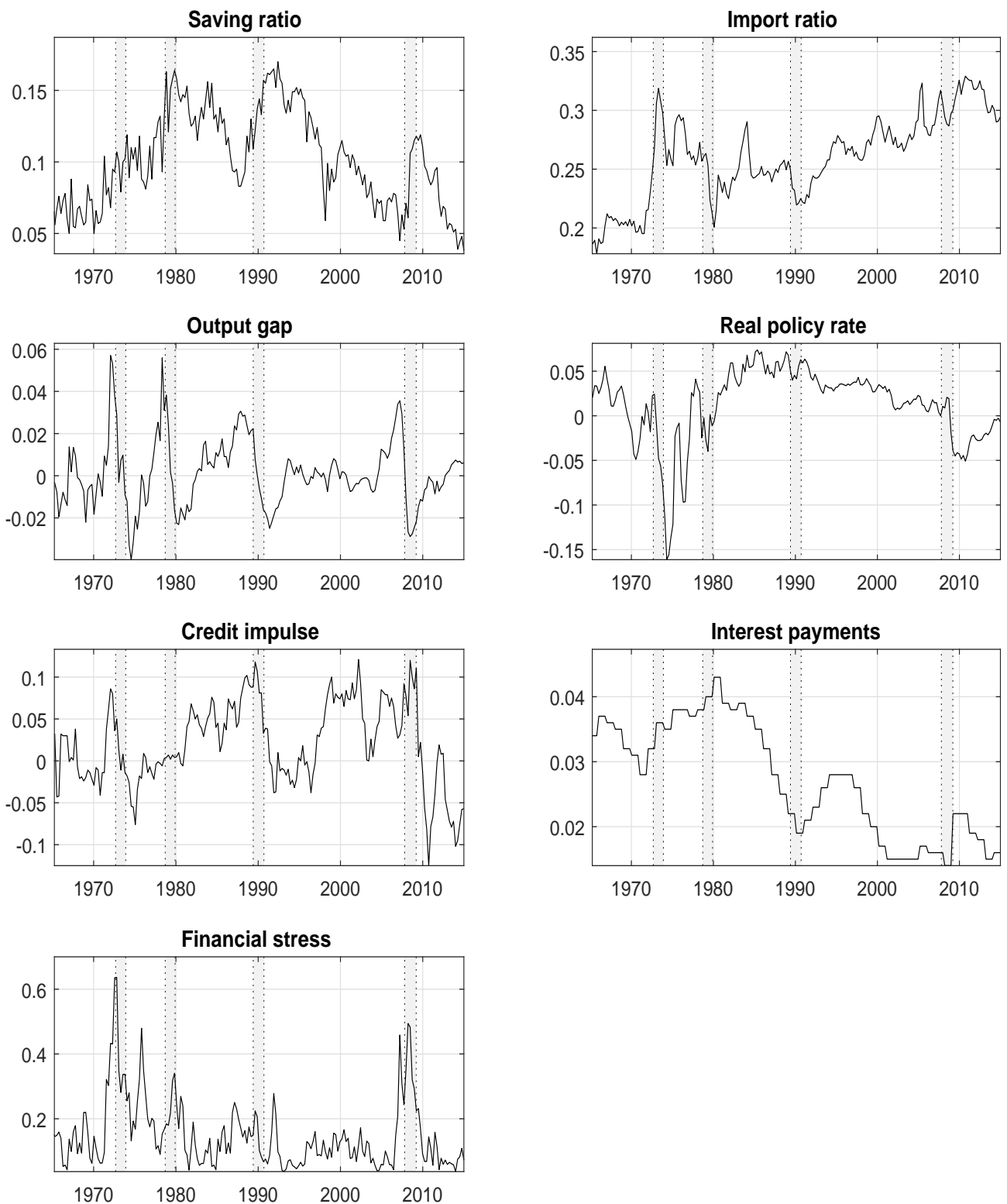

The results in Table 1 confirm that cyclical variables are important drivers of timevariation. In particular, we find evidence for a significant effect of economic slack, financial frictions, and the stance of monetary policy. These coefficients have the expected signs and are statistically significant at the $95 \%$ level. In particular, if the output gap increases 
TABLE 1. Estimated long-run coefficients from the Bayesian regression (12)

\begin{tabular}{|c|c|}
\hline Output gap & $-36.04^{* *}$ \\
\hline Real policy rate & $-9.24^{* *}$ \\
\hline Credit impulse & $-5.54^{* *}$ \\
\hline Financial stress & $12.23^{* *}$ \\
\hline Interest payments & $-14.20^{* *}$ \\
\hline Saving ratio & -25.74 \\
\hline Import ratio & -33.64 \\
\hline ZLB & -3.41 \\
\hline Trend & 0.03 \\
\hline Constant term & $9.77^{* *}$ \\
\hline Standard error & $0.01^{* *}$ \\
\hline Observations & 170 \\
\hline Durbin-Watson & 1.96 \\
\hline Adjusted $R^{2}$ & 0.94 \\
\hline \multicolumn{2}{|c|}{$\begin{array}{l}\text { Notes: The dependent variable is the posterior distribution of the } \\
\text { various fiscal spending multipliers for output defined in Section } 4.1 \\
\left.\text { and shown in Figure } 1 .{ }^{* *}\right] \text { indicate statistical significance of the } \\
\text { long-run coefficients at } 95 \% \text { level. }\end{array}$} \\
\hline
\end{tabular}

by one percentage point, then the overall negative impact on the 2-year multiplier amounts to 0.36. This is a comparably large change as the average value of the multiplier over the sample is 0.48. Financial frictions also matter, as the credit-impulse measure is negatively associated with the size of the multiplier (one percentage point increase lowers the multiplier by 0.06) and the financial stress index is positively associated (an increase by 0.1 units, approximately one standard deviation of the index, raises the multiplier by 1.2). Finally, a high real policy rate decreases the output multiplier (one percentage point increase lowers the multiplier by 0.09), suggesting that multipliers are larger when monetary policy is loose. The ZLB dummy does not show up significantly, in line with previous visual evidence.

Regarding the influence of structural variables, we find that the chosen measure of fiscal space affects the size of the multiplier: the ratio of government interest payments to GDP enters negatively and is statistically significant. The saving ratio and import ratio 
enter with the negative sign predicted by Keynesian theory, but they are not statistically significant at the $95 \%$ level. ${ }^{24}$

To assess the quantitative importance of the regressors, we provide a decomposition of the fitted values from regression (12) into the contribution of each regressor (we present here results only for those variables in Table 1 whose coefficients are significant at the $95 \%$ level). ${ }^{25}$ Figure 4 shows the contribution of each regressor in explaining the variation of the output multiplier over time. Consider the subplot of regressor $i$, the graph shows the time series of the cumulative output multiplier (equal to the solid line in Figure 1), next to the gap (black bars) between the predicted values (1) once using all values of regressor $i$ and (2) when regressor $i$ is kept fixed at its mean value. Note that this exercise should not be considered as a proper counter-factual simulation because the series are correlated. It provides however further evidence on the relevance of each variable in explaining the variation of the UK multiplier at each point in time, in addition to the average results shown in Table 1.

Several results are worth mentioning:

(1) The output gap variable is explaining an important part of the cyclical variation of the multiplier, with spikes at each recession episode, including the 1990 one.

(2) The real policy rate seems to be one additional factor behind the small value of the government spending multipliers in the 1980s and 1990s, including the 1990-91 recession episode. The fall in the size of the multiplier for output at the beginning of the 1980s and its small value throughout this decade and the following one correspond well to the strong increase observed in the real rate over the same period, and is consistent with the negative and persistent contribution of this variable to the fitted value of our regression. In fact, the negative contribution of the real policy rate counteracts the positive contribution from the output gap during the recession episode of the early 90, which provides a further explanation of why this recession is indeed different from the others in our sample.

(3) Among the variables measuring financial frictions, the financial stress index increases the multiplier substantially in the two recessions of the 70s and during the great financial

\footnotetext{
${ }^{24} \mathrm{We}$ also performed various extensions to this Bayesian linear regression model. The first element of choice therein is the length of the horizon $\mathcal{P}$ of the cumulative multiplier. We extended the horizon $\mathcal{P}$ from eight in several steps up to 32 which corresponds to eight years. None of the regressors' sign and level of statistical significance changed. We also performed regressions using alternative output gap measures based on univariate filters, such as the Christiano-Fitzgerald filter, the Hodrick-Prescott filter and the Baxter-King filter. None of the results changed. Results are available upon request.

${ }^{25} \mathrm{~A}$ similar exercise is conducted by Berg (2015) to assess the contribution of different explanatory variables to the German fiscal multiplier.
} 
FiguRE 4. Bayesian linear regression - decomposition

The figure shows the contribution of each regressor in explaining the variation of the cumulative multiplier for output. Consider the subplot of regressor $i$, the plot shows the time series of the prediction for the impact multiplier (solid line), next to the gap (black bars) between the predicted values (1) once using all values of regressor $i$ and (2) when regressor $i$ is kept fixed at its mean value.
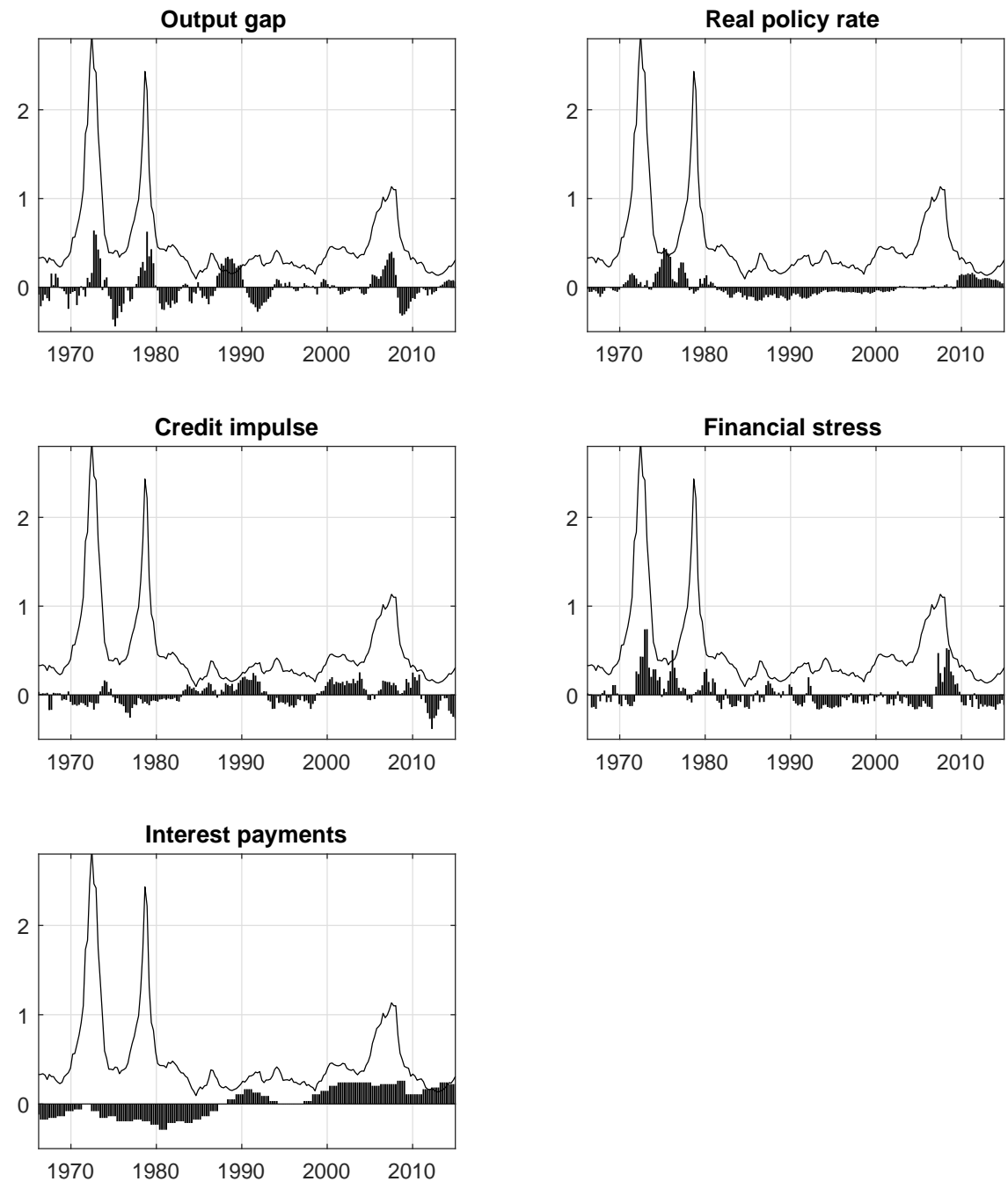

crisis. Its contribution seems to be negligible during the 1990 recession. The contribution of the credit impulse variable is generally small.

(4) Low interest payments on government debt contributed positively to the fitted values of the UK output multiplier during the past 15 years. This is true also from 2008 onwards, even though government debt has passed from about 40\% of GDP in 2007 to about 90\% of GDP in 2015. This is likely due to the fact that interest rates remained very low in the 
last part of the sample, as a result of the accommodative monetary policy stance carried out by the Bank of England.

Overall, results on the transmission mechanisms are in line with the empirical literature that emphasizes cyclical factors - in particular, the role of the business cycle (Auerbach and Gorodnichenko, 2012, 2013; Rafiq, 2014; Dell'Erba et al., 2018) and of financial conditions (Corsetti et al., 2012; Ferraresi et al., 2015; Borsi, 2018; Pragidis et al., 2018). Structural factors - in the form of fiscal space - also play a role, as in Corsetti et al. (2012), Ilzetzki et al. (2013) and Nickel and Tudyka (2014). Finally, our results are consistent with the literature that does not find systematically higher fiscal multipliers at the ZLB (Swanson and Williams, 2014; Bredemeier et al., 2015; Debortoli et al., 2018; Li and Tian, 2018). Overall, however, cyclical factors dominate structural factors in explaining the variation of the UK government spending multiplier of output.

\section{Robustness}

We present here some robustness exercises carried out along two main dimensions. First, we assess the sensitivity of our results with respect to the calibration of the prior densities. Second, we evaluate the robustness of our results with respect to alternative ways of identifying the policy shock.

6.1. Calibration of the priors. This subsection investigates the role of priors for our results. As detailed in the appendix, priors need to be specified for the regression coefficients at the beginning of the estimation period (initial states) as well as for the degree to which these coefficients can change over time. Our baseline priors are as follows:

$$
\begin{aligned}
\tilde{\Phi}_{0} & \sim N\left(\tilde{\Phi}_{0, O L S}, 4 \cdot \operatorname{Var}\left(\tilde{\Phi}_{0, O L S}\right)\right) \\
A_{0} & \sim N\left(A_{0, O L S}, 4 \cdot \operatorname{Var}\left(A_{0, O L S}\right)\right) \\
\tilde{\sigma}_{0} & \sim N\left(\tilde{\sigma}_{0, O L S}, I_{n_{y}+k}\right) \\
Q_{\tilde{\Phi}} & \sim I W\left(k_{Q_{\tilde{\Phi}}}^{2} \cdot 40 \cdot \operatorname{Var}\left(\tilde{\Phi}_{0, O L S}\right), 40\right) \\
Q_{\tilde{a}} & \sim I W\left(k_{Q_{\tilde{a}}}^{2} \cdot 2 \cdot \operatorname{Var}\left(A_{0, O L S}\right), 2\right) \\
Q_{\tilde{\sigma}} & \sim I W\left(k_{Q_{\tilde{\sigma}}}^{2} \cdot 4 \cdot I_{n_{y}+k}, 4\right)
\end{aligned}
$$

The parameters with subscript OLS correspond to the point estimates of a training sample from 1960:Q1 to 1965:Q4. Furthermore, we set $k_{Q_{\tilde{\Phi}}}=0.01, k_{Q_{\tilde{a}}}=0.01, k_{Q_{\tilde{\sigma}}}=0.01$. This means that standard deviation of the innovations in equation (3) equal to $1 \%$ of the standard error of the OLS estimates (e.g., see Stock and Watson (1996) and Cléaud et al. $(2013))$. 
While the choice of the priors for the initial states is completely innocuous, the selection of the hyperparameters $k_{Q_{\tilde{\Phi}}}, k_{Q_{\tilde{a}}}$ and $k_{Q_{\tilde{\sigma}}}$ is more important. In large samples, as usual, the posterior mean converges to the maximum likelihood estimator. However, with limited data, posterior inference is affected by the choice of the hyperparameters. Our values for $k_{Q_{\tilde{\Phi}}}$ and $k_{Q_{\tilde{\sigma}}}$ correspond to those in the literature (Stock and Watson, 1996; Cogley and Sargent, 2002; Primiceri, 2005). $k_{Q_{\tilde{a}}}$ is set smaller than standard (the standard value in the literature is 0.1). As detailed below, we found that the results become volatile and unstable with the standard calibration and therefore chose a parameter that implies less variation in the off-diagonal matrices of the covariance matrix.

In the left panels of Figure 5 we contrast our results for the cumulative output multiplier, as depicted in Figure 1, with estimates based on different values for all hyperparameters $\left(k_{Q_{\tilde{\Phi}}}, k_{Q_{\tilde{a}}}\right.$ and $\left.k_{Q_{\tilde{\sigma}}}\right)$. The figure shows the baseline result jointly with the confidence intervals. Additionally, we plot in green the median value of the fiscal output multiplier for alternative calibrations of the hyperparameters (four times smaller and four times larger). We observe that once choosing higher or smaller values, though still in a reasonable range, our results remain basically unchanged. In particular, the difference in the estimates of the government spending multiplier are not statistically significant, as shown in the bottom part of the panels (note that, for all models, the same random draws are used). The main difference is that in the case of a higher value for the hyperparameters, the confidence intervals (not reported here) expand noticeably (see Stock and Watson (1996); Cléaud et al. (2013), among others, for similar findings).

The right panels in Figure 5 show the sensitivity of the results with respect to $k_{Q_{\tilde{a}}}$ only. Changing this hyperparameter within a reasonable range leaves our results fairly unchanged. However, if we were to increase this parameter up to a value close to 0.1 , as it is standard in the literature, then the results of the median multiplier would become volatile and confidence bands increase considerably. The difference to our baseline specification remains, however, statistically insignificant.

6.2. Alternative identification approaches. This subsection assesses the robustness of our results to alternative methods to identify government spending shocks. We consider two alternative approaches to our baseline identification outlined in Section 3.4 : (i) the first builds upon our baseline identification scheme, though considers different variables in the vector $X_{t}^{1}$ (see section 3.4); (ii) the second considers sign restrictions in order to identify the government spending shock.

As regards the first approach, we vary the two variables to which government spending does not respond contemporaneously in $X_{t}^{1}$, selecting eight variables that are standard in 
FiguRE 5. Prior hyperparameters

The figure shows the government spending output multiplier for different values of the hyperparameters $k_{Q_{\tilde{\Phi}}}, k_{Q_{\tilde{a}}}$ and $k_{Q_{\tilde{\sigma}}}$. The baseline result uses: $k_{Q_{\tilde{\Phi}}}=k_{Q_{\tilde{a}}}=k_{Q_{\tilde{\sigma}}}=0.01$. The confidence intervals shown here are the ones from the baseline calibration. The bottom part of each subplot shows the difference between the baseline multiplier and the alternative one jointly with the $68 \%$ confidence interval.
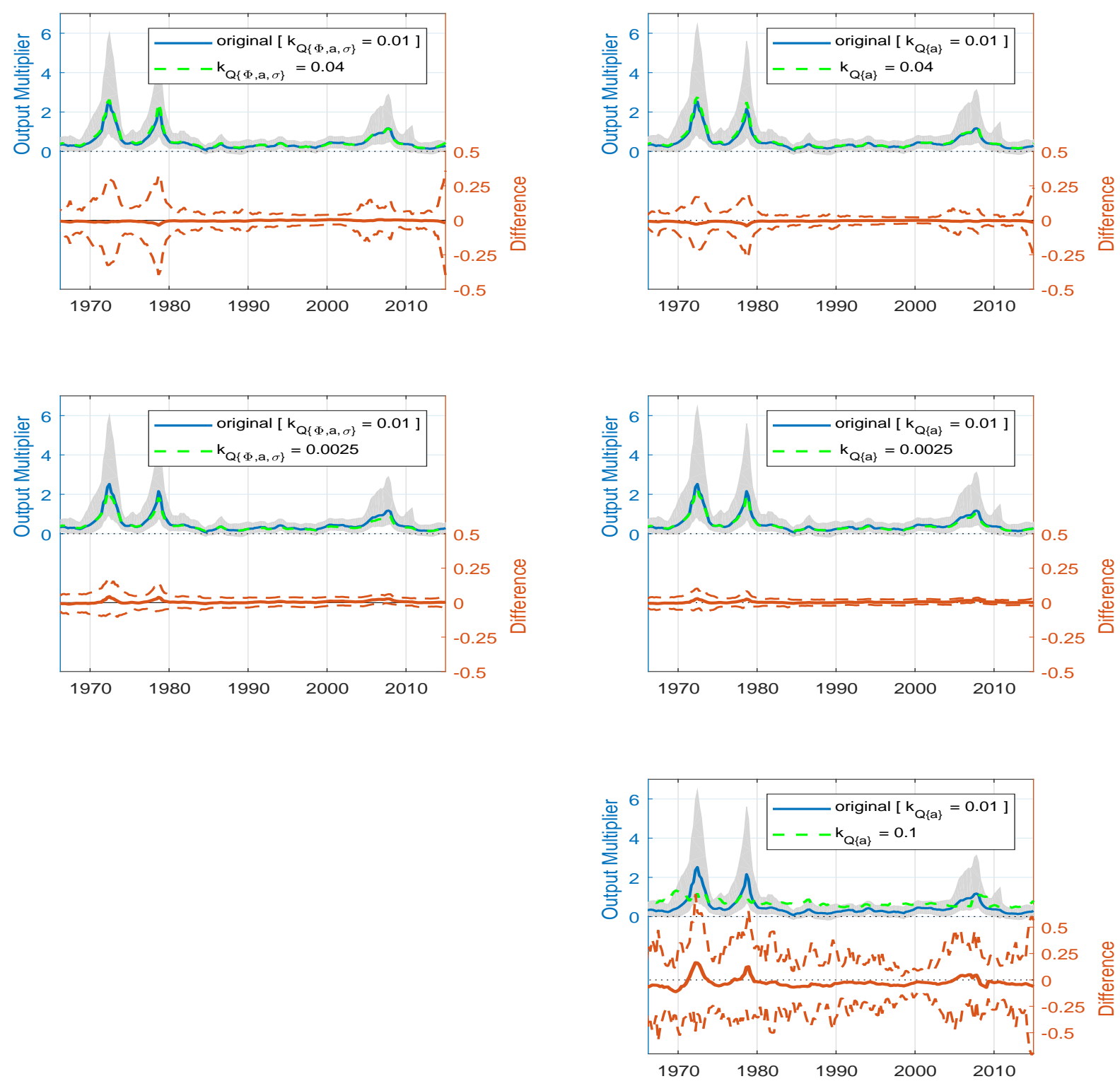

the literature: private household consumption, total investment, the policy rate, the 10 year government bond rate, imports of goods and services, the GDP deflator, wages and unemployment. We use every possible combination of these variables and compute the 
median impulse response function of output for each permutation. In Figure 6 we show the minimum and maximum of the median impulse response functions of GDP across all permutations (there are 28 permutations in total) excluding our baseline identification.

The second robustness exercise identifies the policy shock through sign restrictions (Canova and Nicoló, 2002; Uhlig, 2005). In particular, we impose three alternative sets of restrictions to identify an expansionary government spending shock. These restrictions are similar to those applied for instance by Forni and Gambetti (2010) and Enders et al. (2011). The idea is that economic theory gives a number of restrictions on how macroeconomic variables respond to a government spending shock that can be used for identification. In sum, we use some or all of the following restrictions: an exogenous increase in government spending increases output, lowers unemployment (because of higher demand) and increases inflation (because of higher demand) and leads to a tighter monetary policy (because of higher inflation). Sign Restr.\#1 includes the following restrictions: government spending $(+)$, unemployment $(-)$, GDP deflator $(+)$ and the policy rate $(+)$; Sign Restr. \#2 includes the following restrictions: government spending (+), GDP (+), unemployment (-), GDP deflator $(+)$ and the policy rate $(+)$; Sign Restr.\#3 includes the following restrictions: government spending $(+)$, GDP $(+)$ GDP deflator $(+)$ and the policy rate $(+)$. In each case, we impose the sign restrictions over a horizon of two quarters. We report the median impulse response function among the set of accepted impulse response functions.

The impulse response functions of GDP with respect to the various identification approaches are shown in Figure 6 for three different years $(1974,2005,2008)$; in each case we show the baseline identification (solid black line) and the alternative identification schemes (green dotted lines).

We observe that the shape of the impulse response functions of the various alternative identification schemes closely mimics the one of the baseline results for each of the three years considered. Moreover, the impulse response functions of the alternative identifications are in most cases within the $68 \%$ error band of the baseline results. We conclude that alternative identifications schemes have only a minor impact on the results.

\section{Conclusion}

So, do UK government spending multipliers vary over time? Based on the results from our model estimated over the past 50 years, it looks like they do. To summarize, we find that government spending multipliers are typically above one in recessions and below one in expansion periods, so that most of their variation is cyclical. This applies to output, as well as to other demand components, such as private consumption and investment. 
FiguRE 6. Impulse response functions of GDP - Alternative identification approaches

The Figure reports the impulse response functions of GDP to a surprise innovation in government spending for different identification approaches (Permutation, Sign Restr.\#1, Sign Restr.\#2, Sign Restr.\#3). The impulse response functions are shown for a horizon of up to 32 quarters ( 8 years). The first row shows the min and max responses of the permutation exercise, the remaining rows show the median responses from the identification based on sign restrictions. The columns refer to different points in time.
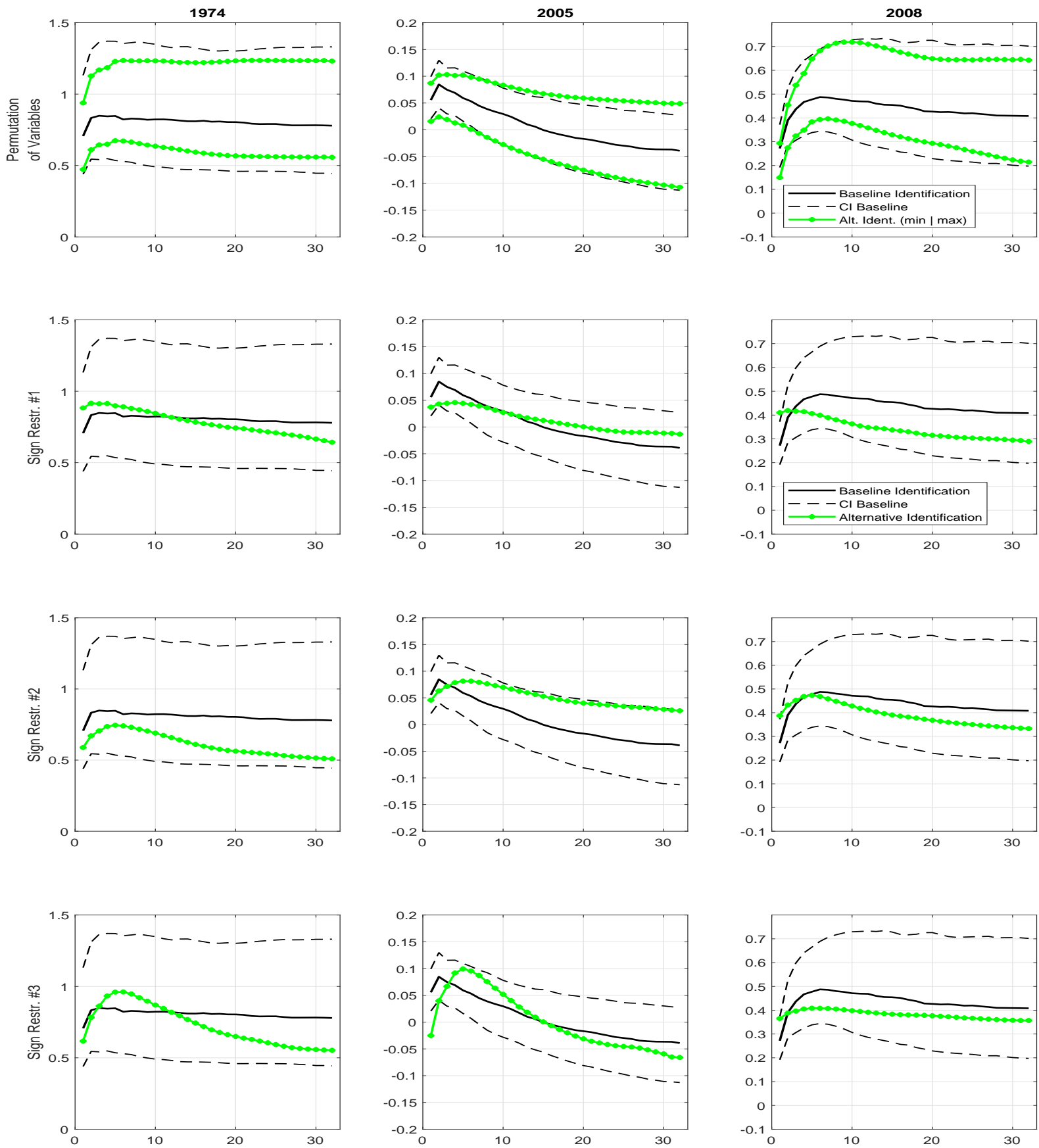
Regarding the drivers of the cyclical variation, our results are consistent with theories emphasizing the role of financial frictions and economic slack. We find no evidence instead for multipliers being systematically larger at the zero lower bound. However, monetary policy is relevant since the degree of monetary accommodation, measured in the paper by the level of the real policy rate, is an additional factor driving the size of the output multiplier. Finally, we find that multipliers do not exhibit a clear trend and that structural factors play a lesser role than cyclical ones in explaining their variations, with fiscal space being the only significant one.

Despite of the flexibility and richness of our econometric framework, other relevant questions related to the broad topic of the effects of fiscal policy to the economy remain beyond the scope of this paper. Two examples are the composition of fiscal adjustments in assessing their effects on output, since we only consider shocks to government consumption expenditure, and the response of taxes to government spending shocks, so that the overall fiscal policy effect may differ.

Given the evidence from our model, we conclude that fiscal policy recommendations should take into account the position of the economy in the cycle in assessing their effectiveness. In particular, we find that in non-recessionary periods the impact of fiscal spending shocks is limited as crowding-out effects are large, suggesting a cautionary tale for fiscal policy to stimulate output in the UK during expansionary phases of the business cycle. 


\section{REFERENCES}

Almeida, Vanda, Gabriela Castro, Ricardo Mourinho Félix, and José R. Maria (2013) 'Measuring the output responses to fiscal policy.' International Journal of Central Banking 4(9), 1-38

Amir-Ahmadi, Pooyan, Christian Matthes, and Mu-Chun Wang (2015) 'Measurement errors and monetary policy: Then and now.' Working Papers 15-13, Federal Reserve Bank of Richmond, November

Auerbach, Alan J., and Yuriy Gorodnichenko (2012) 'Measuring the output responses to fiscal policy.' American Economic Journal: Economic Policy 4(2), 1-27

(2013) 'Fiscal multipliers in recession and expansion.' In Fiscal Policy after the Financial Crisis, ed. Alberto Alesina and Francesco Giavazzi (University of Chicago Press) pp. 63-98

Bachmann, Rüdiger, and Eric R. Sims (2012) 'Confidence and the transmission of government spending shocks.' Journal of Monetary Economics 59(3), 235-249

Bai, Jushan, and Pierre Perron (1998) 'Estimating and testing linear models with multiple structural changes.' Econometrica 66(1), 47-78

Bai, Jushan, and Pierre Perron (2003) 'Computation and analysis of multiple structural change models.' Journal of Applied Econometrics 18(1), 1-22

Bai, Jushan, and Serena Ng (2002) 'Determining the number of factors in approximate factor models.' Econometrica 70(1), 191-221

(2006) 'Confidence intervals for diffusion index forecasts and inference for factoraugmented regressions.' Econometrica 74(4), 1133-1150

Barro, Robert J., and Charles J. Redlick (2011) 'Macroeconomic effects from government purchases and taxes.' The Quarterly Journal of Economics 126(1), 51-102

Bates, Brandon J., Mikkel Plagborg-Møller, James H. Stock, and Mark W. Watson (2013) 'Consistent factor estimation in dynamic factor models with structural instability.' Journal of Econometrics 177(2), 289-304

Baum, Anja, Marcos Poplawski-Ribeiro, and Anke Weber (2012) 'Fiscal multipliers and the state of the economy.' IMF Working Paper 286

Baumeister, Christiane, and Luca Benati (2013) 'Unconventional Monetary Policy and the Great Recession: Estimating the Macroeconomic Effects of a Spread Compression at the Zero Lower Bound.' International Journal of Central Banking 9(2), 165-212

Berg, Tim Oliver (2015) 'Time varying fiscal multipliers in Germany.' Review of Economics $66(1), 13-46$ 
Bernanke, Ben S., Jean Boivin, and Piotr Eliasz (2005) 'Measuring the effects of monetary policy: A factor-augmented vector autoregressive (FAVAR) approach.' The Quarterly Journal of Economics 120(1), 387-422

Blanchard, Olivier, and Roberto Perotti (2002) 'An empirical characterization of the dynamic effects of changes in government spending and taxes on output.' The Quarterly Journal of Economics 117(4), 1329-1368

Borio, Claudio (2014) 'The financial cycle and macroeconomics: What have we learnt?' Journal of Banking and Finance 45(C), 182-198

Borsi, Mihály (2018) 'Fiscal multipliers across the credit cycle.' Journal of Macroeconomics 56(C), 135-151

Bredemeier, Christian, Falko Juessen, and Andreas Schabert (2015) 'Fiscal policy, interest rate spreads, and the zero lower bound.' Discussion Papers 8993, IZA

Canova, Fabio, and Gianni De Nicoló (2002) 'Monetary disturbances matter for business fluctuations in the G-7.' Journal of Monetary Economics 49(6), 1131-1159

Canova, Fabio, Luca Gambetti, and Evi Pappa (2007) 'The structural dynamics of output growth and inflation: Some international evidence.' Economic Journal 117(519), 167191

Canzoneri, Matthew, Fabrice Collard, Harris Dellas, and Behzad Diba (2016) 'Fiscal multipliers in recessions.' The Economic Journal 126(590), 75-108

Christiano, Lawrence, Martin Eichenbaum, and Sergio Rebelo (2011) 'When is the government spending multiplier large?' Journal of Political Economy 119(1), 78 - 121

Cimadomo, Jacopo, and Agnès Bénassy-Quéré (2012) 'Changing patterns of fiscal policy multipliers in Germany, the UK and the US.' Journal of Macroeconomics 34(3), 845-873

Cléaud, Guillaume, Matthieu Lemoine, and Pierre-Alain Pionnier (2013) 'Which size and evolution of the government expenditure multiplier in france (1980-2010)?' Working paper 469, Banque de France

Cloyne, James (2013) 'Discretionary tax changes and the macroeconomy: New narrative evidence from the United Kingdom.' American Economic Review 4(103), 1507-1528

Coenen, Günter, Christopher J. Erceg, Charles Freedman, Davide Furceri, Michael Kumhof, René Lalonde, Douglas Laxton, Jesper Lindé, Annabelle Mourougane, Dirk Muir, Susanna Mursula, Carlos de Resende, John Roberts, Werner Roeger, Stephen Snudden, Mathias Trabandt, and Jan in't Veld (2012) 'Effects of fiscal stimulus in structural models.' American Economic Journal: Macroeconomics 4(1), 22-68

Cogley, Timothy, and Thomas J. Sargent (2002) 'Evolving post-world war II U.S. inflation dynamics.' In 'NBER Macroeconomics Annual 2001, Volume 16' (MIT Press) pp. 331388 
(2005) 'Drift and volatilities: monetary policies and outcomes in the post WWII US.' Review of Economic Dynamics 8(2), 262-302

Corsetti, Giancarlo, Andre Meier, and Gernot J. Müller (2012) 'What determines government spending multipliers?' Economic Policy 27(72), 521-565

Debortoli, Davide, Jordi Galí, and Luca Gambetti (2018) 'On the Empirical (Ir)Relevance of the Zero Lower Bound Constraint.' Working Papers 1013, Barcelona Graduate School of Economics

Del Negro, Marco, and Giorgio E. Primiceri (2015) 'Time-varying structural vector autoregressions and monetary policy: a corrigendum.' The Review of Economic Studies $82(4), 1342-1345$

Dell'Erba, Salvatore, Ksenia Koloskova, and Marcos Poplawski-Ribeiro (2018) 'Mediumterm fiscal multipliers during protracted economic contractions.' Journal of Macroeconomics 56, 35-52

Duprey, Thibaut, Benjamin Klaus, and Tuomas Peltonen (2017) 'Dating systemic financial stress episodes in the EU countries.' Journal of Financial Stability 32(C), 30-56

Eggertsson, Gauti B. (2011) 'What fiscal policy is effective at zero interest rates?' In 'NBER Macroeconomics Annual 2010, Volume 25' NBER Chapters (National Bureau of Economic Research, Inc) pp. 59-112

Enders, Zeno, Gernot Müller, and Almuth Scholl (2011) 'How do fiscal and technology shocks affect real exchange rates? New evidence for the United States.' Journal of International Economics 83(1), 53-69

Ferraresi, Tommaso, Andrea Roventini, and Giorgio Fagiolo (2015) 'Fiscal policies and credit regimes: a TVAR approach.' Journal of Applied Econometrics 30(7), 1047-1072

Forni, Mario, and Luca Gambetti (2010) 'Fiscal foresight and the effects of government spending.' CEPR Discussion Papers 7840, C.E.P.R. Discussion Papers (2014) 'Sufficient information in structural VARs.' Journal of Monetary Economics 66(C), 124-136

Fragetta, Matteo, and Emanuel Gasteiger (2014) 'Fiscal foresight, limited information and the effects of government spending shocks.' Oxford Bulletin of Economics and Statistics 76(5), 667-692

Galí, Jordi, J. David López-Salido, and Javier Vallés (2007) 'Understanding the effects of government spending on consumption.' Journal of the European Economic Association $5(1), 227-270$

Gechert, Sebastien (2015) 'What fiscal policy is most effective? A meta regression analysis.' Oxford Economic Papers 67(3), 553-580 
Gechert, Sebastien, and Ansgar Rannenberg (2018) 'Which fiscal multipliers are regimedependent? A meta-regression analysis.' Journal of Economic Survey 32(4), 1160-1182

Geweke, John (1992) 'Evaluating the accuracy of sampling-based approaches to the calculation of posterior moments.' In 'Bayesian Statistics' University Press pp. 169-193

Geweke, John (1993) 'Bayesian treatment of the independent student-t linear model.' Journal of Applied Econometrics 8(S), 19-40

Glocker, Christian, and Philipp Wegmüller (2018) 'International evidence of timevariation in trend labor productivity growth.' Economics Letters 167(C), 115-119

Hauptmeier, Sebastian, Jacopo Cimadomo, and Markus Kirchner (2010) 'Transmission of government spending shocks in the euro area: Time variation and driving forces.' Working Paper Series 1219, European Central Bank, July

Hernàndez de Cos, Pablo, and Enrique Moral-Benito (2016) 'Fiscal multipliers in turbulent times: the case of Spain.' Empirical Economics 50(4), 1589-1625

Ilzetzki, Ethan, Enrique G. Mendoza, and Carlos A. Vègh (2013) 'How big (small?) are fiscal multipliers?' Journal of Monetary Economics 60(2), 239 - 254

Jordà, Oscar (2005) 'Estimation and inference of impulse responses by local projections.' American Economic Review 95(1), 161-182

Jordà, Oscar, Moritz Schularick, and Alan M. Taylor (2013) 'When credit bites back.' Journal of Money, Credit and Banking 45(2), 3-28

Kim, Wongi (2015) 'Do government spending multipliers depend on the level of government debt? US historical data evidence.' Applied Economics Letters 22(8), 668-672

Koop, Gary, and Dimitris Korobilis (2010) 'Bayesian multivariate time series methods for empirical macroeconomics.' Foundations and Trends in Econometrics 3(4), 267-358

Koop, Gary, Dale J. Poirier, and Justin L. Tobias (2007) Bayesian Econometric Methods (Cambridge University Press)

Korobilis, Dimitris (2009) 'Assessing the transmission of monetary policy shocks using dynamic factor models.' Working Paper Series 35_09, The Rimini Centre for Economic Analysis

(2013) 'Assessing the transmission of monetary policy using time-varying parameter dynamic factor models.' Oxford Bulletin of Economics and Statistics 75(2), 157-179

Krugman, Paul (2015) 'The austerity delusion.' https://www.theguardian.com/business/nginteractive/2015/apr/29/the-austerity-delusion

Li, Rong, and Xiaohui Tian (2018) 'Spending reversals and fiscal multipliers under an interest rate peg.' Journal of Money, Credit and Banking 50(4), 789-815

Michaillat, Pascal (2014) 'A theory of countercyclical government multiplier.' American Economic Journal: Macroeconomics 6(1), 190-217 
Mineshima, Aiko, Marcos Poplawski-Ribeiro, and Anke Weber (2014) 'Size of fiscal multipliers.' In Post-Crisis Fiscal Policy, ed. Carlo Cottarelli, Philip Gerson, and Abdelhak Senhadji (MIT Press) chapter 12, pp. 315 - 372

Mountford, Andrew, and Harald Uhlig (2009) 'What are the effects of fiscal policy shocks?' Journal of Applied Econometrics 24(6), 960-992

Nickel, Christiane, and Andreas Tudyka (2014) 'Fiscal stimulus in times of high debt: Reconsidering multipliers and twin deficits.' Journal of Money, Credit and Banking 46(7), 1313-1344

Owyang, Michael T., Valerie A. Ramey, and Sarah Zubairy (2013) 'Are government spending multipliers greater during periods of slack? Evidence from twentieth-century historical data.' American Economic Review: Papers \& Proceedings 103(3), 129-34

Perotti, Roberto (1999) 'Fiscal policy in good times and bad.' The Quarterly Journal of Economics 114(4), 1399-1436

Pragidis, Ioannis, Panagiotis Tsintzos, and Vasilios Plakandaras (2018) 'Asymmetric effects of government spending shocks during the financial cycle.' Economic Modelling 68(C), 372-387

Primiceri, Giorgio E. (2005) 'Time varying structural vector autoregressions and monetary policy.' Review of Economic Studies 72(3), 821-852

Rafiq, Sohrab (2014) 'UK fiscal multipliers in the postwar era: Do state dependent shocks matter?' CESifo Economic Studies 60(1), 213-245

Ramey, Valerie A. (2011) 'Identifying government spending shocks: It's all in the timing.' The Quarterly Journal of Economics 126(1), 1-50

(2018) 'Ten years after the financial crisis: What have we learned from the renaissance in fiscal research?' Prepared for the NBER Conference 'Global Financial Crisis at 10 '

Ramey, Valerie A., and Sarah Zubairy (2018) 'Government spending multipliers in good times and in bad: Evidence from US historical data.' Journal of Political Economy $126(2), 850-901$

Reinhart, Carmen, and Kenneth Rogoff (2011) 'From financial crash to debt crisis.' American Economic Review 101(5), 1676-1706

Riera-Crichton, Daniel, Carlos A. Vegh, and Guillermo Vuletin (2015) 'Procyclical and countercyclical fiscal multipliers: Evidence from OECD countries .' Journal of International Money and Finance 52(C), 15 - 31

Rogoff, Kenneth (2013) 'Britain should not take its credit status for granted.' Financial Times, 2. October 2013 
Stock, James H., and Mark W. Watson (1996) 'Evidence on structural instability in macroeconomic time series relations.' Journal of Business $\& 5$ Economic Statistics $14(1), 11-30$

Stock, J.H., and M.W. Watson (2016) 'Dynamic factor models, factor-augmented vector autoregressions, and structural vector autoregressions in macroeconomics.' In Handbook of Macroeconomics, ed. John B. Taylor and Harald Uhlig, vol. 2 (Elsevier) chapter 8, pp. $415-525$

Swanson, Eric T., and John C. Williams (2014) 'Measuring the effect of the zero lower bound on medium- and longer-term interest rates.' American Economic Review 104(10), 3154-3185

Trichet, Jean-Claude (2010) 'Interview with La Repubblica 16 June 2010.' http://www.ecb.europa.eu/press/key/date/2010/html/sp100624.en.html

Uhlig, Harald (2005) 'What are the effects of monetary policy on output? Results from an agnostic identification procedure.' Journal of Monetary Economics 52(2), 381-419

Woodford, Michael (2011) 'Simple analytics of the government expenditure multiplier.' American Economic Journal: Macroeconomics 3(1), 1-35 


\section{Appendix A. Markov Chain Monte Carlo (MCMC) estimation}

In this appendix we explain the Bayesian estimation and the simulation of the observation and state equation of the TVP-FAVAR model, i.e., equation (1) and (3) in the main paper, and provide diagnostic checks for the convergence of the Markov Chain Monte Carlo algorithm. We refer to Primiceri (2005) and Baumeister and Benati (2013) for a more detailed outline.

A.1. Simulating the observation equation. Because the $n_{x}$ equations in equation system (3) of the main paper are independent, we can sample the parameter matrices $\Lambda^{f}$ and $\Lambda^{y}$ equation-by-equation. Subsequently, we have $n_{x}$ univariate regression models and a standard conjugate prior (Normal-Gamma) that can be used for the parameters (Koop et al., 2007). In particular, we use a non-informative prior of the form:

$$
\begin{gathered}
\Lambda^{f} \sim N(0, \zeta \cdot I) \\
\left(\omega_{i}^{e}\right)^{-2} \sim \Gamma(\alpha, \beta)
\end{gathered}
$$

where $\Omega^{e}=\operatorname{diag}\left(\left(\omega_{1}^{e}\right)^{2}, \ldots,\left(\omega_{n_{x}}^{e}\right)^{2}\right)$. We specify uninformative values for the parameters $\alpha, \beta$ and $\zeta$.

A.2. Prior distributions for the TVP-FAVAR state equation. As regards the prior distributions, we closely follow Primiceri (2005); Del Negro and Primiceri (2015) and Korobilis (2013).

Overall, the priors take the form:

$$
\begin{aligned}
\tilde{\Phi}_{0} & \sim N\left(\tilde{\Phi}_{0, O L S}, 4 \cdot \operatorname{Var}\left(\tilde{\Phi}_{0, O L S}\right)\right) \\
A_{0} & \sim N\left(A_{0, O L S}, 4 \cdot \operatorname{Var}\left(A_{0, O L S}\right)\right) \\
\tilde{\sigma}_{0} & \sim N\left(\tilde{\sigma}_{0, O L S}, I_{n_{y}+k}\right) \\
Q_{\tilde{\Phi}} & \sim I W\left(k_{Q_{\tilde{\Phi}}}^{2} \cdot 40 \cdot \operatorname{Var}\left(\tilde{\Phi}_{0, O L S}\right), 40\right) \\
Q_{\tilde{a}} & \sim I W\left(k_{Q_{\tilde{a}}}^{2} \cdot 2 \cdot \operatorname{Var}\left(A_{0, O L S}\right), 2\right) \\
Q_{\tilde{\sigma}} & \sim I W\left(k_{Q_{\tilde{\sigma}}}^{2} \cdot 4 \cdot I_{n_{y}+k}, 4\right)
\end{aligned}
$$

We use the first 6 years (from 1960:Q1 to 1965:Q4) to calibrate the various prior distributions and estimate a time-invariant VAR.

The mean of $\tilde{\Phi}_{0}$ are the $O L S$ point estimates $\left(\tilde{\Phi}_{0, O L S}\right)$ in the time invariant VAR model and the variance is four times its variance, estimated on the small initial training sample. In the same way, a corresponding prior density for $A_{0}$ can be obtained. $\tilde{\sigma}_{0}$ corresponds to the $\log$ of the standard errors in the time-invariant model.

The results are obtained using the following values: $k_{Q_{\tilde{\Phi}}}=0.01, k_{Q_{\tilde{a}}}=0.01, k_{Q_{\tilde{\sigma}}}=0.01$. 


\section{A.3. Simulating the posterior distribution of the TVP-FAVAR state equation.}

We simulate the posterior distribution of the hyperparameters and the states conditional on the data via the MCMC algorithm as described in Primiceri (2005); Del Negro and Primiceri (2015) and Cogley and Sargent (2002, 2005). In what follows, $\xi^{t}$ denotes the entire history of the vector $\xi$ up to time $t$, i.e., $\xi^{t}=\left[\xi_{1}^{\prime}, \ldots \xi_{t}^{\prime}\right]^{\prime} \forall t=1, \ldots, T$, where $T$ is the sample length; and the same for $\tilde{\Phi}^{t}=\left(\tilde{\Phi}_{1}, \ldots, \tilde{\Phi}_{t}\right), A^{t}=\left(A_{1}, \ldots, A_{t}\right)$ and $\Sigma^{t}=\left(\Sigma_{1}, \ldots, \Sigma_{t}\right)$.

To simulate the joint posterior distribution of $\left(\tilde{\Phi}^{T}, A^{T}, \Sigma^{T}, \bar{Q}_{\tilde{\Phi}}, \bar{Q}_{\tilde{\sigma}}\right.$ and $\left.\bar{Q}_{\tilde{a}}\right)$, we use a Gibbs sampling algorithm. The Gibbs sampler is carried out by sequentially drawing time varying coefficients $\left(\tilde{\Phi}^{T}\right)$, contemporaneous relations $\left(A^{T}\right)$, stochastic volatilities $\left(\Sigma^{T}\right)$ and hyperparamters $\left(\bar{Q}_{\tilde{\sigma}}\right.$ and $\left.\bar{Q}_{\tilde{a}}\right)$, given the data. For details regarding the sequential sampling see Primiceri (2005) and Baumeister and Benati (2013). Following, e.g. Primiceri (2005); Cogley and Sargent (2005) we reject the unstable draws, thereby enforcing stationarity.

A.4. Computational details. In the Gibbs sampler posterior draws are correlated. The higher the correlation, the lower is the quality of the draws. In what follows, we discuss if our results are subject to convergence problems.

First, different seeds from the random generator produce the same results. These results are also not sensitive to the initial number of discarded draws or the total number of passes of the Gibbs sampler.

Second, we look at the autocorrelation function of the draws and inefficiency factors (Geweke, 1992; Primiceri, 2005). Low autocorrelations improve efficiency of the sampling. In the large majority of cases the autocorrelations stay below $0.1{ }^{26}$

Figure 7 presents the draws' inefficiency factors (IFs) for the posterior estimates of the parameters. The IFs are defined as the inverse of the relative numerical efficiency measure of Geweke (1992), see Primiceri (2005) and Baumeister and Benati (2013) for details regarding the implementation.

Figure 7 shows the draws' IFs for the model's time-varying coefficients of the VAR (the $\Phi_{t}$ 's), the volatilities (the $\Sigma_{t}$ 's), and the non-zero elements of the matrix $A_{t} .{ }^{27}$ As the figure indicates, the IFs are well below twenty. As discussed in Primiceri (2005), values below twenty can be considered satisfactory. We conclude that the algorithm has no convergence problems.

\footnotetext{
${ }^{26}$ The corresponding figures are not shown here, but available upon request.

${ }^{27}$ Each number on the $\mathrm{x}$-axis corresponds to a different parameter. For example, if we have three off-diagonal Elements $A_{t}$ for 216 periods, this results in 648 parameters.
} 
Figure 7. Convergence statistics

The figure shows the inefficiency factors for the draws from the ergodic distribution for the model's time-varying parameters in order to check for convergence of the Markov Chain.
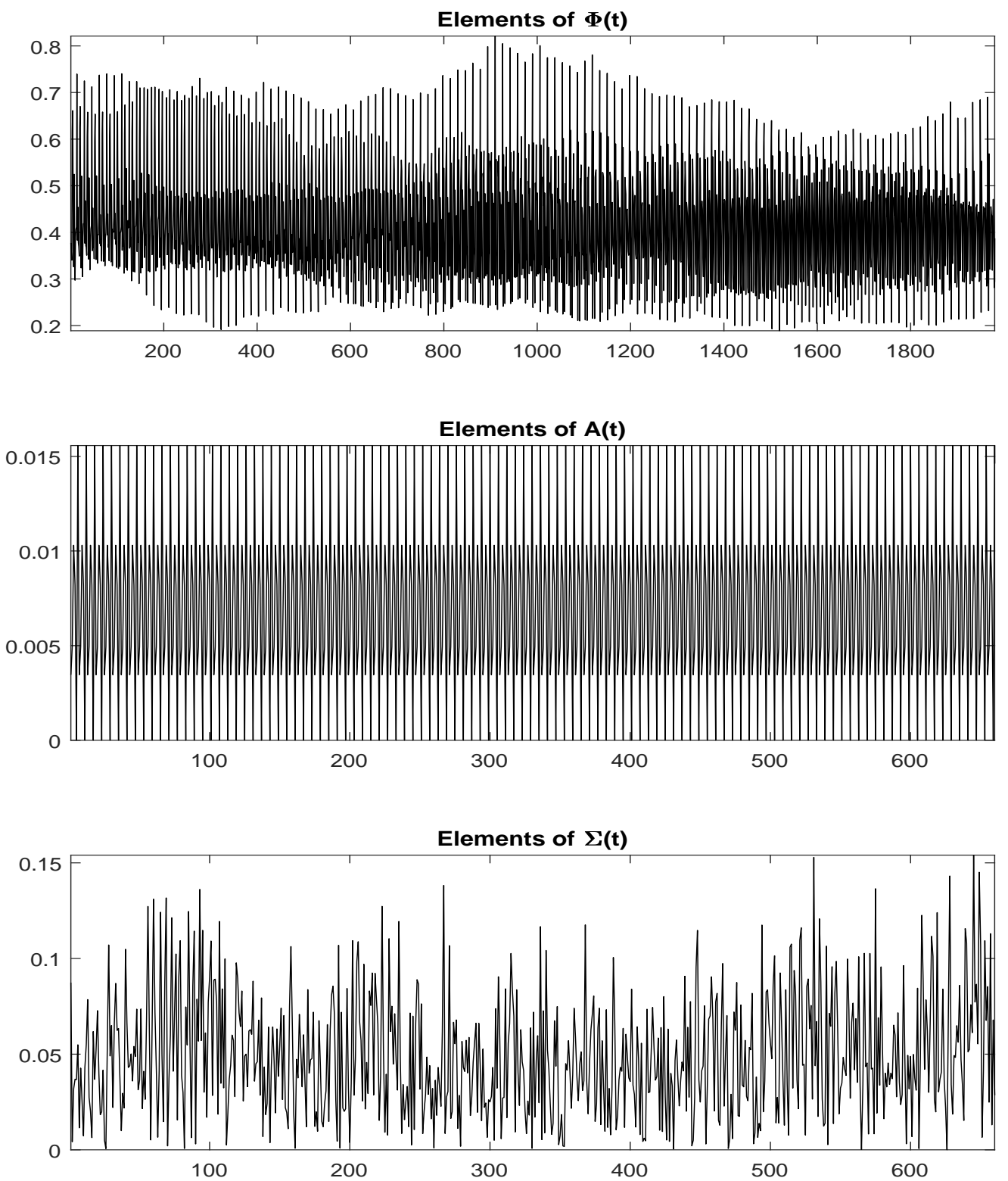

Appendix B. Estimate of the MUltiplier BASED ON A ROLLING-REGRESSion APPROACH

In this section we compare our estimation approach to the simpler alternative of using rolling regressions. We estimate the model as depicted in equations (1) to (5) in the main text with a rolling window of 80 quarters. We leave the size of the window fixed and 
move it iteratively forward with each new observation. Having estimated the model, we calculate the output multiplier. As in our baseline approach, the factor loadings are kept fixed.

Figure 8 shows the corresponding path of the multiplier jointly with a 68 -confidenceband. Overall, the results indicate that a rolling regression approach might lead to misleading inference about the evolution of the spending multiplier. While the approach confirms that the fiscal multiplier has increased after the 2008 recession, the increase is delayed and occurs when the recession has ended. Before the global financial crisis, the estimation suggests a slight structural downward trend, contrary to our finding using a time-varying parameter approach. The confidence band is on average rather wide and would at times even consider a negative value for the output multiplier as reasonable. Compared to our time-varying parameter method, we cannot make any statements about the behaviour of the multiplier in the recessionary episodes during the Seventies, as they are part of the initial window. Finally, we find that the profile of the multiplier is sensitive to the size of the window. Naturally, a shorter window size produces more volatile and imprecise estimates of the multiplier.

\section{Appendix C. Data used in the TVP-FAVAR MOdeL}

All series were downloaded from the statistical Database of Thomson Reuters Datastream and cover the period Q1:1960 until Q4:2015 on a quarterly frequency.

All variables are transformed to be approximately stationary. In particular, if $z_{i, t}$ is the original untransformed series, the transformation codes are: 1 - no transformation $\left(x_{i, t}=z_{i, t}\right), 2$ - first difference of $\operatorname{logarithm}\left(x_{i, t}=\Delta \log \left(z_{i, t}\right)\right)$. The transformations of the variables are indicated in column $T C$ in Table 2.

We denote with an asterisk the variables used in regression (12) in the paper that are not taken from Datastream. In particular, the variables in Figure 3 are defined as follows: the import ratio is constructed as nominal imports relative to nominal GDP; the measure of the output-gap is taken from the OECD statistics database; the real policy rate is constructed as the difference between the Bank of England policy rate minus the contemporaneous CPI inflation rate; the credit impulse variable is constructed as the year-on-year change in the stock of credit to the private sector relative to nominal GDP; the variable capturing interest rate payments on public debt over GDP is taken from the UK Institute for Fiscal Studies; and finally, the financial market stress indicator is taken from Duprey et al. (2017). 
FiguRE 8. Output multiplier based on a rolling-regression approach

The figure shows the government expenditures multiplier for output based on a rollingestimation approach (with a rolling window of 80 quarters). The confidence intervals shown are $68 \%$-confidence bands.

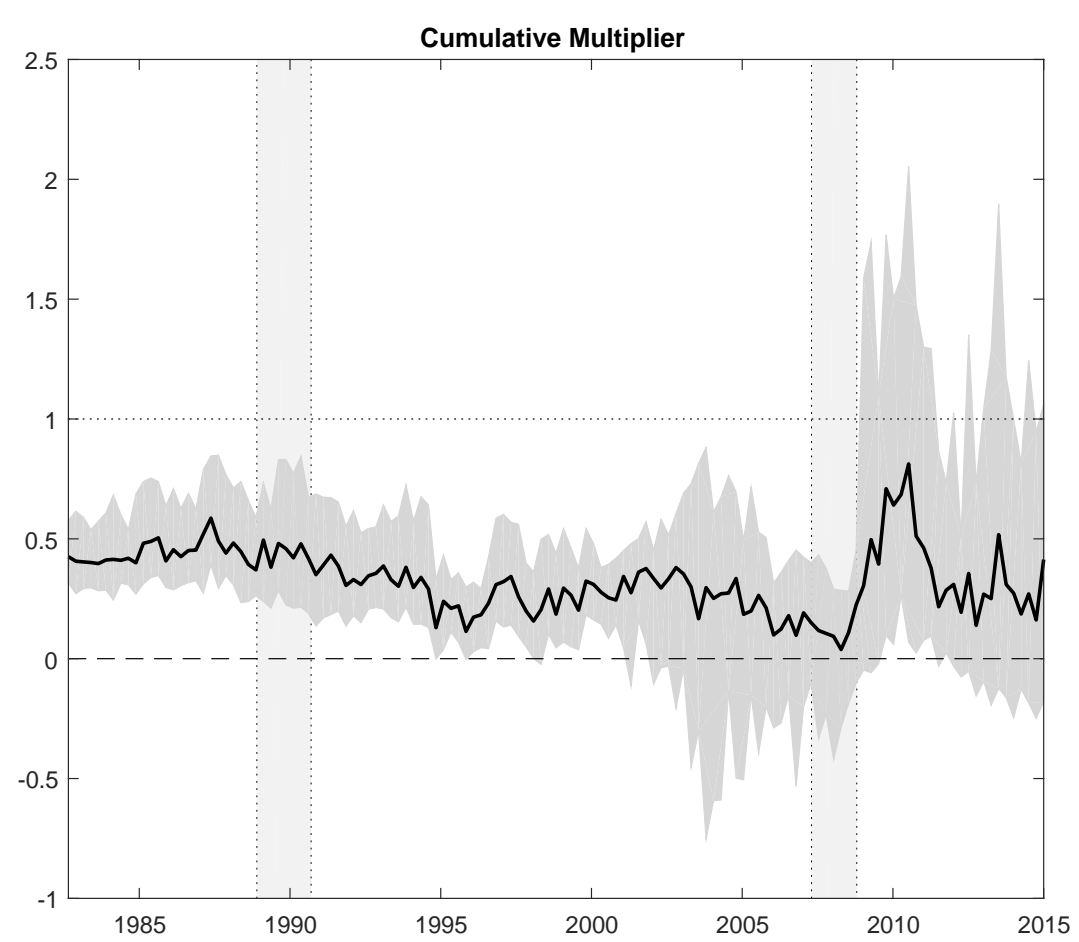


TABle 2. Data used in paper

\begin{tabular}{|c|c|c|c|c|c|}
\hline & Name & Code & Source & Measure & $\mathrm{TC}$ \\
\hline 1 & $\begin{array}{l}\text { BoP: current account balance as per cent of GDP, Current } \\
\text { Prices, SA, GBP [BoP: current account balance as per cent } \\
\text { of GDP] [BOP: CURRENT ACCOUNT BALANCE (\% OF } \\
\text { GDP) ] }\end{array}$ & UKAA6H..Q & $\begin{array}{l}\text { Office for } \mathrm{Na}- \\
\text { tional Statistics }\end{array}$ & SA & 1 \\
\hline 2 & $\begin{array}{l}\text { Balance of Payments: Trade in Goods \& Services: Total } \\
\text { exports, Constant Prices, SA, GBP [ BOP: EXPORTS - } \\
\text { TRADE IN GOODS \& SERVICES ] }\end{array}$ & UKIKBK.. & $\begin{array}{l}\text { Office for } \mathrm{Na}- \\
\text { tional Statistics }\end{array}$ & $\begin{array}{l}\text { Constant } \\
\text { prices, SA }\end{array}$ & 2 \\
\hline 3 & $\begin{array}{l}\text { BoP: trade in goods and services balance as per cent of GDP, } \\
\text { Current Prices, SA, GBP [ BOP: GOODS \& SERVICES } \\
\text { BALANCE ( } \% \text { OF GDP) ] }\end{array}$ & UKD28L..Q & $\begin{array}{l}\text { Office for } \mathrm{Na}- \\
\text { tional Statistics }\end{array}$ & SA & 1 \\
\hline 4 & $\begin{array}{l}\text { Balance of Payments: Trade in Goods \& Services: TO- } \\
\text { TAL IMPORTS OF GOODS \& SERVICES, SA, GBP, } 2005 \\
\text { CHND PRC [ BOP: IMPORTS - TRADE IN GOODS \& } \\
\text { SERVICES ] }\end{array}$ & UKIKBL..D & $\begin{array}{l}\text { Office for } \mathrm{Na}- \\
\text { tional Statistics }\end{array}$ & $\begin{array}{l}\text { Constant } \\
\text { prices, SA }\end{array}$ & 2 \\
\hline 5 & $\begin{array}{l}\text { Changes in inventories including alignment adjustment, } \\
\text { Constantt Prices, SA, GBP [ CHANGES IN INVENTO- } \\
\text { RIES ] }\end{array}$ & UKCAFU..D & $\begin{array}{l}\text { Office for } \mathrm{Na}- \\
\text { tional Statistics }\end{array}$ & $\begin{array}{l}\text { Constant } \\
\text { prices, SA }\end{array}$ & 1 \\
\hline 6 & $\begin{array}{l}\text { Income Approach, Gross Domestic Product Components, } \\
\text { Compensation of Employees, Total, Current Prices, SA, } \\
\text { British Pound Sterling [ UK COMPENSATION OF EM- } \\
\text { PLOYESS ] }\end{array}$ & UKDTWM..B & $\begin{array}{l}\text { Office for } \mathrm{Na}- \\
\text { tional Statistics }\end{array}$ & $\begin{array}{l}\text { Current prices, } \\
\text { SA }\end{array}$ & 2 \\
\hline 7 & $\begin{array}{l}\text { Construction Output, All Work, Constant Prices, SA, In- } \\
\text { dex, } 2012=100 \text { [ CONSTRUCTION OUTPUT - TOTAL } \\
\text { WORK ] }\end{array}$ & UKCVCONAG & $\begin{array}{l}\text { Office for } \mathrm{Na}- \\
\text { tional Statistics }\end{array}$ & $\begin{array}{l}\text { Volume index, } \\
\text { SA }\end{array}$ & 2 \\
\hline 8 & $\begin{array}{l}\text { Main Gross Domestic Product Aggregates (ESA2010), } \\
\text { Gross Domestic Product and Main Components, Final Con- } \\
\text { sumption Expenditure and Gross Capital Formation, Cal- } \\
\text { endar Adjusted, SA, Index, } 2010=100 \text { [ DOMESTIC DE- } \\
\text { MAND (VOL.) ] }\end{array}$ & UKESFKKZE & EUROSTAT & $\begin{array}{l}\text { Constant } \\
\text { Prices, SA }\end{array}$ & 2 \\
\hline 9 & $\begin{array}{l}\text { Implicit Price Deflator (IPD), Gross domestic expenditure, } \\
\text { SA, Index, 2006=100 [Total domestic expenditure deflator: } \\
\text { SA] [DOMESTIC EXPENDITURE DEFLATOR - TOTAL } \\
\text { ] }\end{array}$ & UKYBFV...E & $\begin{array}{l}\text { Office for } \mathrm{Na}- \\
\text { tional Statistics }\end{array}$ & Price index, SA & 2 \\
\hline 10 & $\begin{array}{l}\text { Household final consumption expenditure: National con- } \\
\text { cept, Constant Prices, SA, GBP [ FINAL CONSUMP- } \\
\text { TION EXPENDITURE: HOUSEHOLD - NATIONAL } \\
\text { CONCEPT ] }\end{array}$ & UKABJR..D & $\begin{array}{l}\text { Office for } \mathrm{Na}- \\
\text { tional Statistics }\end{array}$ & $\begin{array}{l}\text { Constant } \\
\text { prices, SA }\end{array}$ & 2 \\
\hline
\end{tabular}




\begin{tabular}{|c|c|c|c|c|c|}
\hline & Name & Code & Source & Measure & $\mathrm{TC}$ \\
\hline 11 & $\begin{array}{l}\text { Production Approach, Gross Domestic Product, Total, Con- } \\
\text { stant Prices, SA, GBP, } 2006 \text { chnd prices [ GDP AT CON- } \\
\text { STANT PRICES (CVM) ] }\end{array}$ & UKGDP...D & $\begin{array}{l}\text { Office for } \mathrm{Na}- \\
\text { tional Statistics }\end{array}$ & $\begin{array}{l}\text { Constant } \\
\text { prices, SA }\end{array}$ & 2 \\
\hline 12 & $\begin{array}{l}\text { GROSS FIXED CAPITAL FORMATION (CVM), SA, } \\
\text { GBP, } 2005 \text { CHND PRC [ GFCF (CVM) ] }\end{array}$ & UKGFCF..D & $\begin{array}{l}\text { Office for } \mathrm{Na}- \\
\text { tional Statistics }\end{array}$ & $\begin{array}{l}\text { Constant } \\
\text { prices, SA }\end{array}$ & 5 \\
\hline 13 & $\begin{array}{l}\text { Expenditure Approach, Gross Final Expenditure, Total, } \\
\text { Constant Prices, SA, GBP, } 2006 \text { chnd prices [ GROSS FI- } \\
\text { NAL EXPENDITURE ] }\end{array}$ & UKABMG..D & $\begin{array}{l}\text { Office for } \mathrm{Na}- \\
\text { tional Statistics }\end{array}$ & $\begin{array}{l}\text { Constant } \\
\text { prices, SA }\end{array}$ & 2 \\
\hline 14 & $\begin{array}{l}\text { Income Approach, National Income, Gross Disposable, at } \\
\text { market prices, Constant Prices, SA, Index, 2006=100 [ } \\
\text { GROSS NATIONAL DISPOSABLE INCOME INDEX ] }\end{array}$ & UKYBFP..G & $\begin{array}{l}\text { Office for } \mathrm{Na}- \\
\text { tional Statistics }\end{array}$ & $\begin{array}{l}\text { Volume index, } \\
\text { SA }\end{array}$ & 2 \\
\hline 15 & $\begin{array}{l}\text { Income Approach, National Income, Gross, at market } \\
\text { prices, Current Prices, SA, GBP [ GROSS NATIONAL IN- } \\
\text { COME ] }\end{array}$ & UKGNP...B & $\begin{array}{l}\text { Office for } \mathrm{Na}- \\
\text { tional Statistics }\end{array}$ & $\begin{array}{l}\text { Current prices, } \\
\text { SA }\end{array}$ & 2 \\
\hline 16 & $\begin{array}{l}\text { Income Approach, Allocation of Primary Income Account, } \\
\text { Resources, Private Non-Financial Corporations, Gross op- } \\
\text { erating surplus, Current Prices, SA, GBP [ GROSS OPER- } \\
\text { ATING SURPLUS: PRIVATE ] }\end{array}$ & UKCAER..B & $\begin{array}{l}\text { Office for } \mathrm{Na}- \\
\text { tional Statistics }\end{array}$ & $\begin{array}{l}\text { Current prices, } \\
\text { SA }\end{array}$ & 2 \\
\hline 17 & $\begin{array}{l}\text { Income Approach, Allocation of Primary Income Account, } \\
\text { Public Corporations, Gross operating surplus, Current } \\
\text { Prices, SA, GBP [ GROSS OPERATING SURPLUS: PUB- } \\
\text { LIC ] }\end{array}$ & UKCAEQ..B & $\begin{array}{l}\text { Office for } \mathrm{Na}- \\
\text { tional Statistics }\end{array}$ & $\begin{array}{l}\text { Current prices, } \\
\text { SA }\end{array}$ & 2 \\
\hline 18 & $\begin{array}{l}\text { Production Approach, Value Added, Gross, Service Indus- } \\
\text { tries Total, Constant Prices, SA, Index, } 2012=100 \text { [SER- } \\
\text { VICE INDUSTRIES - TOTAL VOLA ] }\end{array}$ & UKL2NC..G & $\begin{array}{l}\text { Office for } \mathrm{Na}- \\
\text { tional Statistics }\end{array}$ & $\begin{array}{l}\text { Volume index, } \\
\text { SA }\end{array}$ & 2 \\
\hline 19 & $\begin{array}{l}\text { HN:Households saving ratio, SA, GBP [ HN: HOUSE- } \\
\text { HOLDS SAVING RATIO ] }\end{array}$ & UKNRJS..E & $\begin{array}{l}\text { Office for } \mathrm{Na}- \\
\text { tional Statistics }\end{array}$ & $\mathrm{SA}$ & 1 \\
\hline 20 & $\begin{array}{l}\text { HN: Real households disposable income, Constant Prices, } \\
\text { SA, GBP [ HN: REAL HOUSEHOLDS DISPOSABLE IN- } \\
\text { COME ] }\end{array}$ & UKNRJR..D & $\begin{array}{l}\text { Office for } \mathrm{Na}- \\
\text { tional Statistics }\end{array}$ & $\begin{array}{l}\text { Constant } \\
\text { prices, SA }\end{array}$ & 2 \\
\hline 21 & $\begin{array}{l}\text { HN: Resources: Disposable income gross: B.6g, Current } \\
\text { Prices, SA, GBP [ HN: RESOURCES: DISPOSABLE IN- } \\
\text { COME GROSS ] }\end{array}$ & UKRPHQ..B & $\begin{array}{l}\text { Office for } \mathrm{Na}- \\
\text { tional Statistics }\end{array}$ & $\begin{array}{l}\text { Current prices, } \\
\text { SA }\end{array}$ & 2 \\
\hline 22 & $\begin{array}{l}\text { HN: Resources: Wages and salaries: D.11, Current Prices, } \\
\text { SA, GB [ HN: RESOURCES: WAGES \& SALARIES ] }\end{array}$ & UKROYJ..B & $\begin{array}{l}\text { Office for } \mathrm{Na}- \\
\text { tional Statistics }\end{array}$ & $\begin{array}{l}\text { Current prices, } \\
\text { SA }\end{array}$ & 2 \\
\hline 23 & $\begin{array}{l}\text { Production Approach, Value Added, Gross, Production To- } \\
\text { tal, Constant Prices, SA, Index, } 2012=100 \text { [ INDUS- } \\
\text { TRIAL PRODUCTION - ALL PRODUCTION INDUS- } \\
\text { TRIES VOLA ] }\end{array}$ & UKK222Q.G & $\begin{array}{l}\text { Office for } \mathrm{Na}- \\
\text { tional Statistics }\end{array}$ & $\begin{array}{l}\text { Volume index, } \\
\text { SA }\end{array}$ & 2 \\
\hline
\end{tabular}




\begin{tabular}{|c|c|c|c|c|c|}
\hline & Name & Code & Source & Measure & TC \\
\hline 24 & $\begin{array}{l}\text { Main Gross Domestic Product Aggregates (ESA2010), } \\
\text { Gross Domestic Product and Main Components, Taxes } \\
\text { Less Subsidies On Products, Constant Prices, Calendar Ad- } \\
\text { justed, SA, Euro, } 2010 \text { Chained Prices [ TAXES LESS SUB- } \\
\text { SIDIES ON PRODS., } 2010 \text { EUR(ESA2010) (WDA) CONA } \\
\text { ] }\end{array}$ & UKES1O0QD & EUROSTAT & $\begin{array}{l}\text { Constant } \\
\text { prices, SA }\end{array}$ & 2 \\
\hline 25 & $\begin{array}{l}\text { Implicit Price Deflator (IPD) OF EXPORTS OF GOODS } \\
\text { AND SERVICES, SA, Index, } 2005=100 \text { [ Implicit Price De- } \\
\text { flator (IPD) OF EXPORTS OF GOODS AND SERVICES } \\
\text { ] }\end{array}$ & UKIPDEXPE & $\begin{array}{l}\text { Datastream } \\
\text { International } \\
\text { Ltd. }\end{array}$ & Price index, SA & 2 \\
\hline 26 & $\begin{array}{l}\text { Implicit Price Deflator (IPD) OF FINAL SALES, SA, In- } \\
\text { dex, } 2005=100 \text { [ Implicit Price Deflator (IPD) OF FINAL } \\
\text { SALES ] }\end{array}$ & UKIPDEXPEFS & $\begin{array}{l}\text { Datastream } \\
\text { International } \\
\text { Ltd. }\end{array}$ & Price index, SA & 2 \\
\hline 27 & $\begin{array}{l}\text { Implicit Price Deflator (IPD) OF GDP MARKET PRICES, } \\
\text { SA, Index, } 2005=100 \text { [ Implicit Price Deflator (IPD) OF } \\
\text { GDP MARKET PRICES ] }\end{array}$ & UKIPDGDP & $\begin{array}{l}\text { Office for } \mathrm{Na}- \\
\text { tional Statistics }\end{array}$ & Price index, SA & 2 \\
\hline 28 & $\begin{array}{l}\text { Implicit Price Deflator (IPD) OF GENERAL GOVERN- } \\
\text { MENT FINAL CONSUMPTION, SA, Index, 2005=100 [ } \\
\text { Implicit Price Deflator (IPD) OF GENERAL GOVERN- } \\
\text { MENT FINAL CONSUMPTION ] }\end{array}$ & UKIPDPUBE & $\begin{array}{l}\text { Datastream } \\
\text { International } \\
\text { Ltd. }\end{array}$ & Price index, SA & 2 \\
\hline 29 & $\begin{array}{l}\text { Implicit Price Deflator (IPD) OF GROSS DOM. FIXED } \\
\text { CAPITAL FORMATION, SA, Index, } 2005=100 \text { [ Implicit } \\
\text { Price Deflator (IPD) OF GROSS DOM. FIXED CAPITAL } \\
\text { FORMATION ] }\end{array}$ & UKIPDINVE & $\begin{array}{l}\text { Datastream } \\
\text { International } \\
\text { Ltd. }\end{array}$ & Price index, SA & 2 \\
\hline 30 & $\begin{array}{l}\text { Implicit Price Deflator (IPD) OF HOUSEHOLD CON- } \\
\text { SUMPTION, SA, Index, } 2005=100[\text { Implicit Price Deflator } \\
\text { (IPD) OF HOUSEHOLD CONSUMPTION }]\end{array}$ & UKIPDHSHE & $\begin{array}{l}\text { Office for } \mathrm{Na}- \\
\text { tional Statistics }\end{array}$ & Price index, SA & 2 \\
\hline 31 & $\begin{array}{l}\text { Implicit Price Deflator (IPD) OF IMPORTS OF GOODS } \\
\text { AND SERVICES, SA, Index, } 2005=100 \text { [ Implicit Price De- } \\
\text { flator (IPD) OF IMPORTS OF GOODS AND SERVICES } \\
\text { ] }\end{array}$ & UKIPDIMPE & $\begin{array}{l}\text { Datastream } \\
\text { International } \\
\text { Ltd. }\end{array}$ & Price index, SA & 2 \\
\hline 32 & $\begin{array}{l}\text { Income Approach, Allocation of Primary Income Account, } \\
\text { Non-Financial Corporations, Gross operating surplus, Cur- } \\
\text { rent Prices, SA, GBP [ NONFINL. CORPS.: GROSS OP- } \\
\text { ERATING SURPLUS ] }\end{array}$ & UKROZQ..B & $\begin{array}{l}\text { Office for } \mathrm{Na}- \\
\text { tional Statistics }\end{array}$ & $\begin{array}{l}\text { Current prices, } \\
\mathrm{SA}\end{array}$ & 2 \\
\hline 33 & $\begin{array}{l}\text { Output per Filled Job : Whole Economy SA: UK, SA, In- } \\
\text { dex, N/A [ OUTPUT PER FILLED JOB - WHOLE ECON- } \\
\text { OMY ] }\end{array}$ & UKLNNN.. & $\begin{array}{l}\text { Office for } \mathrm{Na}- \\
\text { tional Statistics }\end{array}$ & Price index, SA & 2 \\
\hline
\end{tabular}




\begin{tabular}{|c|c|c|c|c|c|}
\hline & Name & Code & Source & Measure & TC \\
\hline 34 & $\begin{array}{l}\text { Auxiliary Indicators (ESA2010), Population and Employ- } \\
\text { ment, Total Population National Concept, Calendar Ad- } \\
\text { justed, SA [ TOTAL POPULATION NATIONAL CON- } \\
\text { CEPT (ESA2010) (WDA) VOLA ] }\end{array}$ & UKES9YULO & EUROSTAT & Volume, SA & 2 \\
\hline 35 & $\begin{array}{l}\text { Labour Productivity, Output per worker, whole economy, } \\
\text { SA, Index, 2006=100 [ PRODUCTIVITY - OUTPUT PER } \\
\text { WORKER: WHOLE ECONOMY ] }\end{array}$ & UKA4YM..E & $\begin{array}{l}\text { Office for } \mathrm{Na}- \\
\text { tional Statistics }\end{array}$ & $\begin{array}{l}\text { Volume index, } \\
\text { SA }\end{array}$ & 2 \\
\hline 36 & $\begin{array}{l}\text { Whole Economy index of LFS Employment: } 2006=100, \mathrm{SA} \text {, } \\
\text { Index, N/A [ UK WHOLE ECONOMY - EMPLOYMENT } \\
\text { ] }\end{array}$ & UKTXEL..E & $\begin{array}{l}\text { Office for } \mathrm{Na}- \\
\text { tional Statistics }\end{array}$ & $\begin{array}{l}\text { Volume index, } \\
\text { SA }\end{array}$ & 2 \\
\hline 37 & $\begin{array}{l}\text { UNIT LABOUR COST INDEX - WHOLE ECONOMY, } \\
\text { SA, Index, } 2003=100 \text { [ UNIT LABOUR COST INDEX - } \\
\text { WHOLE ECONOMY ] }\end{array}$ & UKLCOST.E & $\begin{array}{l}\text { Office for } \mathrm{Na}- \\
\text { tional Statistics }\end{array}$ & Price index, SA & 2 \\
\hline 38 & $\begin{array}{l}\text { Monetary authorities, Monetary liabilities, NOTES\&COIN } \\
\text { IN CIRC.W/PUBLIC, GBP [ CENTRAL BANK: CUR- } \\
\text { RENCY IN CIRCULATION ] }\end{array}$ & UKQ14A..A & $\begin{array}{l}\text { IMF Interna- } \\
\text { tional Financial } \\
\text { Statistics }\end{array}$ & $\begin{array}{l}\text { Current prices, } \\
\text { not SA }\end{array}$ & 2 \\
\hline 39 & $\begin{array}{l}\text { Depository corporations survey/monetary survey, Domestic } \\
\text { credit, CLAIMS ON PRIVATE SECTOR, GBP [ DOMES- } \\
\text { TIC CREDIT: CLAIMS ON PRIVATE SECTOR ] }\end{array}$ & UKQ32D..A & $\begin{array}{l}\text { IMF Interna- } \\
\text { tional Financial } \\
\text { Statistics }\end{array}$ & $\begin{array}{l}\text { Current prices, } \\
\text { not SA }\end{array}$ & 2 \\
\hline 40 & $\begin{array}{l}\text { Exchange rate, fund position or international liquidity, } \\
\text { FOREIGN EXCHANGE in UK Pound [ FOREIGN EX- } \\
\text { CHANGE RESERVES ] }\end{array}$ & UKQ.1D.DA & $\begin{array}{l}\text { IMF Interna- } \\
\text { tional Financial } \\
\text { Statistics }\end{array}$ & $\begin{array}{l}\text { Current prices, } \\
\text { not SA }\end{array}$ & 2 \\
\hline 41 & $\begin{array}{l}\text { Interest rates prices, production or labour, Earnings, } \\
\text { AV EARN PROD IND SA, BASEYEARTEXT } 2005 \text { [ } \\
\text { WEEKLY WAGES ] }\end{array}$ & UKQ65..CE & $\begin{array}{l}\text { IMF Interna- } \\
\text { tional Financial } \\
\text { Statistics }\end{array}$ & Price index, SA & 2 \\
\hline 42 & $\begin{array}{l}\text { UK DOMESTIC CREDIT: CLAIMS ON OFFICIAL EN- } \\
\text { TITIES CURN [ ] }\end{array}$ & UKQ32BX.A & $\begin{array}{l}\text { IMF Interna- } \\
\text { tional Financial } \\
\text { Statistics }\end{array}$ & no SA & 2 \\
\hline 43 & AVERAGE BRENT OIL PRICE, USD [ OIL PRICE ] & UKOILBREN & $\begin{array}{l}\text { Department of } \\
\text { Energy, U.K. }\end{array}$ & $\begin{array}{l}\text { Price index, } \\
\text { not SA }\end{array}$ & 2 \\
\hline 44 & $\begin{array}{l}\text { Policy Rates, Bank Rate (Shorter History), End of Period, } \\
\text { GBP [ Monetary Policy Rate (EP) ] }\end{array}$ & UKPRATE. & $\begin{array}{l}\text { Bank of Eng- } \\
\text { land }\end{array}$ & Interest Rate & 1 \\
\hline 45 & $\begin{array}{l}\text { CBI SURVEY - OPTIMISM BALANCE (MONTHLY IN- } \\
\text { TERPOLATED) [ CBI SURVEY - OPTIMISM BALANCE } \\
\text { (MONTHLY INTERPOLATED) ] }\end{array}$ & UKCBICONR & $\begin{array}{l}\text { Office for } \mathrm{Na}- \\
\text { tional Statistics }\end{array}$ & Not SA & 1 \\
\hline 46 & $\begin{array}{l}\text { Composite Leading indicators, Trend [ COMPOSITE } \\
\text { LEADING INDICATOR (TREND RESTORED) ] }\end{array}$ & UKCYLEAD & $\begin{array}{l}\text { Main Economic } \\
\text { Indicators, } \\
\text { Copyright } \\
\text { OECD }\end{array}$ & Trends & 2 \\
\hline
\end{tabular}




\begin{tabular}{|c|c|c|c|c|c|}
\hline & Name & Code & Source & Measure & $\mathrm{TC}$ \\
\hline 47 & $\begin{array}{l}\text { RETAIL SALES (MONTHLY ESTIMATE, DS CALCU- } \\
\text { LATED), Constant Prices, SA, GBP, } 2000 \text { prices [ RETAIL } \\
\text { SALES (MONTHLY ESTIMATE DS CALCULATED) ] }\end{array}$ & UKRETTOTD & $\begin{array}{l}\text { Datastream } \\
\text { International } \\
\text { Ltd. }\end{array}$ & $\begin{array}{l}\text { Constant } \\
\text { prices, SA }\end{array}$ & 2 \\
\hline 48 & RPI- INFLATION RATE [ RPI- INFLATION RATE ] & UKRPANNL & $\begin{array}{l}\text { Office for } \mathrm{Na}- \\
\text { tional Statistics }\end{array}$ & & 1 \\
\hline 49 & $\begin{array}{l}\text { RPI:Percentage change over } 12 \text { months - all items excluding } \\
\text { housing, GBP [RPI: ALL ITEMS EXCLUDING HOUSING } \\
(\% \text { YOY) ] }\end{array}$ & UKCZBI.. & $\begin{array}{l}\text { Office for } \mathrm{Na}- \\
\text { tional Statistics }\end{array}$ & & 1 \\
\hline 50 & $\begin{array}{l}\text { RPI:Percentage change over } 12 \text { months - Clothing and } \\
\text { footwear, GBP [ RPI: CLOTHING \& FOOTWEAR } \\
(\% \text { YOY })]\end{array}$ & UKCZDO.. & $\begin{array}{l}\text { Office for } \mathrm{Na}- \\
\text { tional Statistics }\end{array}$ & & 1 \\
\hline 51 & $\begin{array}{l}\text { RPI:Percentage change over } 12 \text { months - Food excluding } \\
\text { seasonal, GBP [ RPI: FOOD EXCLUDING SEASONAL } \\
(\% \mathrm{YOY})]\end{array}$ & UKCZBQ.. & $\begin{array}{l}\text { Office for } \mathrm{Na}- \\
\text { tional Statistics }\end{array}$ & & 1 \\
\hline 52 & $\begin{array}{l}\text { RPI:Percentage change over } 12 \text { months - Housing, GBP [ } \\
\text { RPI: HOUSING (\%YOY) ] }\end{array}$ & UKCZCP.. & $\begin{array}{l}\text { Office for } \mathrm{Na}- \\
\text { tional Statistics }\end{array}$ & & 1 \\
\hline 53 & $\begin{array}{l}\text { RPI:Percentage change over } 12 \text { months - Seasonal food, } \\
\text { GBP [ RPI: SEASONAL FOOD (\%YOY) ] }\end{array}$ & UKCZBP.. & $\begin{array}{l}\text { Office for } \mathrm{Na}- \\
\text { tional Statistics }\end{array}$ & & 1 \\
\hline 54 & $\begin{array}{l}\text { BIS, Real Narrow Effective Exchange Rate Index, Average, } \\
\text { GBP [ EFFECTIVE EXCHANGE RATE NARROW IN- } \\
\text { DEX - REAL CPI ] }\end{array}$ & UKBISRXNR & $\begin{array}{l}\text { Bank for Inter- } \\
\text { national Settle- } \\
\text { ments }\end{array}$ & Not SA & 1 \\
\hline 55 & $\begin{array}{l}\text { FTSE, All-Share, Index, Price Return, End of Period, GBP } \\
{[\text { FT ALL SHARE INDEX (EP) ] }}\end{array}$ & UKSHRPRCF & Reuters & $\begin{array}{l}\text { Price index, } \\
\text { not SA }\end{array}$ & 2 \\
\hline 56 & $\begin{array}{l}\text { GROSS REDEMPTION YIELD ON } 10 \text { YEAR GILT } \\
\text { EDGED STOCKS (AVERAGE) [ bond yield } 10 \text { YEAR } \\
\text { (AVERAGE) ] }\end{array}$ & UKMEDYLD & $\begin{array}{l}\text { Bank of Eng- } \\
\text { land }\end{array}$ & Interest Rate & 1 \\
\hline 57 & London Interbank Rate - 3 Month (EP) [ LIBOR ] & UKINTERB & $\begin{array}{l}\text { Bank of Eng- } \\
\text { land }\end{array}$ & Interest Rate & 1 \\
\hline 58 & $\begin{array}{l}\text { Output Prices, All manufactured products, Index, } \\
2005=100 \text { [ PPI - OUTPUT OF MANUFACTURED } \\
\text { PRODUCTS }]\end{array}$ & UKPROPRCF & $\begin{array}{l}\text { Office for } \mathrm{Na}- \\
\text { tional Statistics }\end{array}$ & $\begin{array}{l}\text { Price index, } \\
\text { not SA }\end{array}$ & 2 \\
\hline 59 & Unemployment, Rate, SA [ ] & UKUNEMRAT & $\begin{array}{l}\text { Office for } \mathrm{Na}- \\
\text { tional Statistics }\end{array}$ & SA & 1 \\
\hline 60 & $\begin{array}{l}\text { Consumer Surveys, GfK, Consumer Confidence Index, Total } \\
\text { [ ] }\end{array}$ & UKCONSENT & $\begin{array}{l}\text { Office for } \mathrm{Na}- \\
\text { tional Statistics }\end{array}$ & & 1 \\
\hline 61 & $\begin{array}{l}\text { Domestic Trade, Retail Trade, All Retailing, Constant } \\
\text { Prices, SA, Index [ ] }\end{array}$ & UKRETTRAD & $\begin{array}{l}\text { Office for } \mathrm{Na}- \\
\text { tional Statistics }\end{array}$ & $\begin{array}{l}\text { constant prices, } \\
\text { SA }\end{array}$ & 2 \\
\hline 62 & Consumer Price Index, Total, Index [ CPI ] & UKCPITI & $\begin{array}{l}\text { Office for } \mathrm{Na}- \\
\text { tional Statistics }\end{array}$ & Price Index & 2 \\
\hline 63 & Consumer Price Index, Core CPI, Total [ ] & UKCPICOR & $\begin{array}{l}\text { Office for } \mathrm{Na}- \\
\text { tional Statistics }\end{array}$ & Price Index & 2 \\
\hline
\end{tabular}




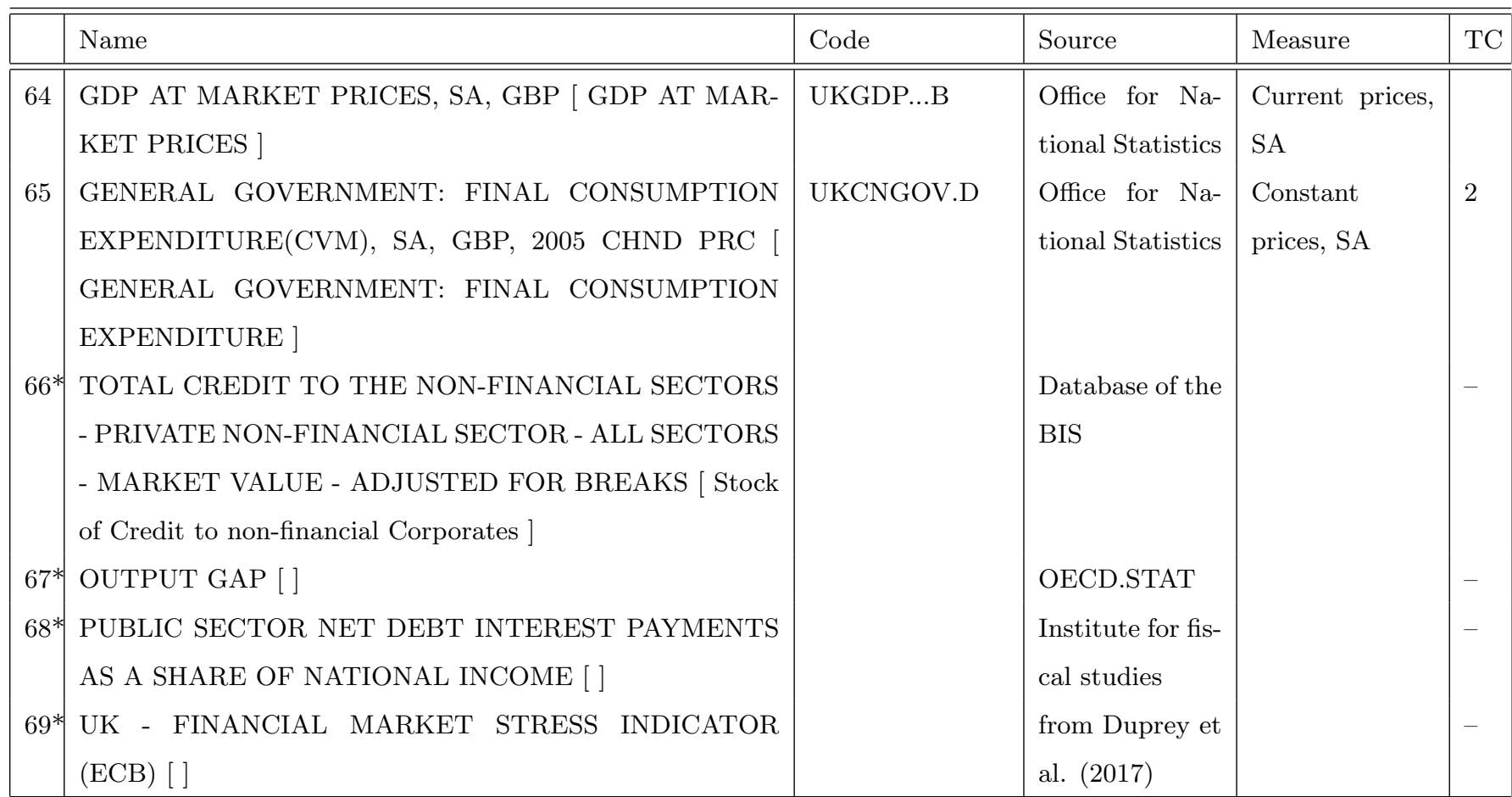

* Data used in the Bayesian linear regression of section 4.2 only. 